\title{
Klasik Arap Şiirinde Güzel Sözün Benzetildiği Unsurlara Dair Literal Bir Tarama*
}

\author{
A Literal Scanning about Elements Resembling Beautiful Words in Classical Arab \\ Poetry
}

Rıfat AKBAŞ**

Öz

Abstract

Klasik Arap edebiyatı kaynaklarında herhangi bir In classical Arab literature sources, it is possible to temanın hangi amaçlarla kullanıldığı ancak sabırlı ve reveal what kinds of aims any theme is used for through itinalı bir literatür taraması sonucu ortaya çıkabilir. Belli a patient and elaborate literature scanning. It is bir tema etrafında teşbih merkezli yapılan itinalı bir doubtless that an academic work, which will emerge literatür taraması sonrasında ortaya çıkacak akademik after a simile oriented literature scanning, carefully bir çalışmanın ilgili alandaki araştırmacılara hem zengin performed around a theme, will not only provide rich bir kaynak sağlayacağı hem de klasik Arap edebiyatının sources for researchers of the field but also it will give an kendisine özgü teşbih dünyasını tanıma fırsatı vereceği opportunity for them to learn the world of simile specific kuşkusuzdur. Bu sebeple gerek Câhiliye döneminde to classical Arab literature itself. For this reason, in this gerekse İslâm sonrası dönemin değişik yüzyıllarında article, the related sections of divan and anthology type yaşamış olan şairlere ait dîvânlar ile antoloji türü works belonging to poets who lived in different centuries eserlerin ilgili bölümleri taranarak hazırlanmış olan bu both during Jahiliyyah and post-Islamic period were makalede, hangi sözlerin hayranlık uyandırıp güzel scanned and prepared, and it was tried to determine the addedildiği veya hangi ifadelerin çirkin görüldüğü only elements which beautiful word was resembled meselesine girilmeden sadece güzel sözün benzetildiği without getting involved in the matter of which words unsurlar tespit edilmeye çalışılmıştır. Şairlerin çeşitli were accepted as beautiful and awoke admiration in benzetmelere başvurarak muhataplarına ince ve anlamlı people. In the article in which the poets tried to send mesajlar vermeye çalıștıklarına işaret eden makalede subtle and meaningful messages to the addressees güzel sözün benzetildiği unsurlardan özellikle edebî employing several similes, of the elements where kaynaklarda yer alan beyitlerin sayısı dikkate alınarak beautiful word was resembled, especially the ones that birden fazla şair tarafından dillendirilenler alt başlıklar were pronounced by more than one poet were şeklinde incelenmiş diğerlerine ise icmâlen değinilmiştir. investigated as sub titles, while the others were Klasik Arap şiirine bağlı kalınarak güzel sözü yalnızca mentioned superficially considering the number of the benzetilen unsurlar ekseninde sistematik bir şekilde konu couplets taking place in the literary sources. Relying on edinen makalenin akademik alanda göze çarpan önemli the classical Arab poetry, it is anticipated that this article, bir boşluğu dolduracağı ümit edilmektedir. which only mentions beautiful word in the axis of resembled elements systematically, will fill an important gap receiving attention in academic filed.

Anahtar Kelimeler: Arap Dili, Arap Edebiyatı, Şiir, Güzel Keywords: Arab Language, Arab Literature, Poetry, Söz, Hoş Söz.

Beautiful Word, Nice Word.

\section{Giriş}

Zekâ süzgecinden geçirilen bir söz aynı zamanda gönle hitap edebilecek bir şekilde ifade edildiği takdirde arzu edilen neticeye ulaşılabilir. Kuşkusuz bu durumun farkında olanların başında edebî sanat ustaları olan şairler gelmektedir. Onlar diğer insanlardan farklı olarak varlığı kendi sanatsal bakış açıları ile değerlendiren, duygu ve düşüncelerini kendilerine özgü bir üslupla kafiyeli, ölçülü ve âhenkli bir şekilde dile

* $\quad$ Geliş Tarihi: 15.10.2021, Kabul Tarihi: 28.12.2021.

** Dr. Öğr. Üyesi, Van Yüzüncü Yıl Üniversitesi İlahiyat Fakültesi, Arap Dili ve Belagatı Bilim Dalı, akbasakbasa.1988@hotmail.com, ORCID: 0000-0002-8533-3335. 
getiren kimselerdir. Geçmişi İslâm öncesi döneme kadar uzanan Arap edebiyatında bazı orijinal tema ve figürlerin çağlar boyunca irdelenmesi araştırmacılar nezdinde bu edebiyatın muhtevasını daha dikkat çekici hale getirmiştir. Söz konusu edebiyatta göze çarpan temalardan biri de evrensel bir değeri haiz olan güzel sözdür.

Aslında bir şeyin güzel sayılması kişiden kişiye, coğrafyadan coğrafyaya değişkenlik arz edebilir. Başka bir deyişle güzel kavramından neyin kast edildiği hususu gerçek dünyadaki maddi ve manevi değerlerin yanı sıra gelenekler ile birlikte çevreden edinilen kültürle de doğrudan bağlantılıdır. Bununla birlikte adalet, eşitlik, saygı, yardımlaşma, merhamet, alçak gönüllülük, diğerkâmlık, güzel ve tatlı söz gibi bazı erdemlerin her kesimin hoşuna gidebileceğini söylemek yanlış olmayacaktır.

Güzel söz hakkında yapılmış olan akademik çalışmalar vardır. Örneğin Ahmet Kazan tarafından hazırlanan Gazzali'nin Ihyau Ulumi'd-din Adll Eserinin 3-4. Ciltlerindeki Güzel Sözler ve Kaynakları başlıklı yüksek lisans tezi bu konuda yapılan önemli bir çalışmadır. ${ }^{1}$ Özellikle tezin ikinci bölümünde âyet ve hadislerden alınan özlü sözler ile peygamberler, sahabe ve büyük şahsiyetlere ait hikmetli sözlere yer verilmiştir. Adem Ceyhan ve Hasan Yılmaz tarafından kaleme alınan Arapçada Güzel Sözler Derlemesi Nesrü'l-Leâlî'nin Mensur Bir Tercümesi adlı makale de bu alana katk1 sunan bir diğer önemli bir çalışmadır. ${ }^{2}$ Şu var ki bahsedilen her iki çalışmada da güzel söz müşebbeh ve müşebbehün bih ekseninde inceleme konusu yapılmamıştır. Bu çalışmada ise güzel söz mahiyet ve içerik bakımından değil sadece benzetmeler özelinde ele alınmıştır. Çalışma makale düzeyinde bir araştırma olduğu için istişhâd bazında aktarılan beyitlerin gramatik tahlillerine yer verilmemiştir.

\section{Güzel Söz Anlamında Kullanılan Ifadeler}

"Güzel söz" tabiri bir sıfat tamlaması olduğu için bu tamlamanın anlamını verecek müfred bir sözcük bulunmamaktadır. Bu yüzden "söz" anlamına gelen

$1 \quad$ Bkz. Ahmet Kazan, Gazzali'nin İhyau Ulumi'd-din Adlı Eserinin 3-4. Ciltlerindeki Güzel Sözler ve Kaynakları (İstanbul: Marmara Üniversitesi, Sosyal Bilimler Enstitüsü, Yüksek Lisans Tezi, 2009), 33-90.

$2 \quad$ Bkz. Adem Ceylan - Hasan Yılmaz, “Arapçada Güzel Sözler Derlemesi Nesrü'l-Leâlî’nin Mensur Bir Tercümesi”, Celal Bayar Üniversitesi Sosyal Bilimler Dergisi, 17/3 (2019), 99-125. 
sözcükler güzellik, yumuşaklık, tatlılık, hoşluk, vb. gibi nitelemeleri aldıkları zaman 'güzel söz' terkibi ortaya çıkmaktadır. Örneğin Kur'ân-1 Kerîm'de yer alan

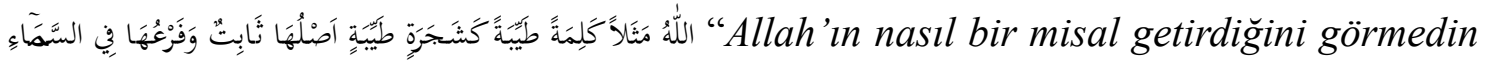
mi? Güzel sözü, kökü sabit, dallarl gökte olan güzel bir ă̆aca benzetti."3 âyeti gibi Arap

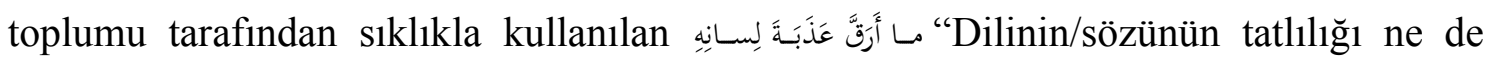

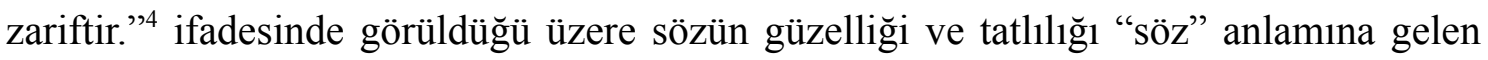
kelimelerin öncesinde veya sonrasında zikredilen tamamlayıcı ibarelerle belirlenmiştir.

Klasik Arap şiirinde genellikle kelâm (كلام), elfâz (الفاظ), ahbâr (أخبار), ibârât (عبارا)

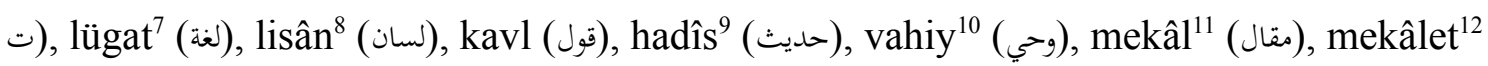

3 Kur'an Yolu (Erișim 6 Temmuz 2021), İbrahim 14/24.

4 Ebû Muhammed Sâbit b. Ebî Sâbit Saîd el-Kûfî el-Lugavî, Halku'l-insân, thk. Abdüssettâr Ahmed Ferrâc (Kuveyt: Matbaatu Hukûmeti Kuveyt, 1985), 181.

5 Ebû Osmân Amr b. Bahr b. Mahbûb el-Câhiz, el-Beyân ve't-tebyîn, thk. Abdüsselâm Muhammed Hârûn (Kahire: Mektebetü'l-Hânecî, 1418/1998), 1/277.

6 Siracüddin Muhammed, Mevsû 'atu revâi 'i’ş-şi 'ri'l-'Arabî (Beyrut: Dâru’r-Râtibi'l-Câmiiyye, ts.), $4 / 24$.

7 Ebû Sa'd, Süveyd b. Kâhil b. Hârise el-Yeşkûrî, Dîvânu Süveyd b. Ebî Kâhil el-Yeşkûrî, thk. Şakir elÂşûr (Dımaşk: 2012), 51.

8 Ebû Saîd el-Hasen b. el-Hüseyn b. Ubeydillâh el-Atekî es-Sükkerî, Dîvânü Ebi'l-Esved ed-Dü'elî, thk. Muhammed Hasan Âl Yasin (Beyrut: Dâru Mektebeti'l-Hilâl, 1418/1998), 40; Ebü's-Saâdât Ziyâüddîn Hibetullah b. Alî b. Muhammed İbnü'ş-Şecerî, Muhtârâtü şu'arâ'i'l-'Arab, thk. Ali Muhammed el-Bicâvî (Beyrut: Dâru'l-Cîl, 1412/1992), 32.

9 Ebû Muhammed Abdullāh b. Müslim İbn Kuteybe ed-Dîneverî, eş-Şi 'r ve'ş-şu'arâ', thk. Ahmed Muhammed Şakir, Kahire: Dâru'l-Maârif, 1377/1957), 2/616; Ebû Hilâl el-Hasen b. Abdillâh b. Sehl el-Askerî, Dîvânü'l-me 'ânî, thk. Ahmed Selim Gânim (b.y: Dâru'l-Garbi'l-İslâmî, 1424/2003), 1/482, 483.

10 Ebû Muhammed Abdullah b. Müslim İbn Kuteybe ed-Dîneverî, 'Uyûnü'l-ahbâr (Beyrut: Dâru'lKitâbi'l-Arabî, 1343/1925), 4/82.

11 Ebû Ömer Şihâbüddîn Ahmed b. Muhammed İbn Abdirabbih, el- 'ịkdü'l-ferîd, thk. Müfid Muhammed Kumayha (Beyrut: Dâru'l-Kutubi'l-İlmiyye, 1404/1983), 2/280.

12 Ebû İshâk İbrâhîm b. Alî b. Temîm el-Ensârî el-Husrî, Zehrü'l-âdâb ve semerü'l-elbâb, haz. Selahüddin el-Hevârî (Beyrut: el-Mektebetü'l-Asriyye Seydâ, 1421/2001), 1/35. 
(مقالة), nutk (نطق), (منطق), ${ }^{13}$ mantık $^{14}$ mizved $^{15}$ (مذود), kevâfî16 (قوافي) ve şevârid ${ }^{17}$ (شوارد) şeklinde göze çarpan kavramların tümü söz anlamında kullanılmaktadır. Dolayısıyla yukarıda değinildiği üzere bu kavramlara hoş, yumuşak, tatlı vb. gibi nitelemeler birleştirildiği takdirde "güzel söz" manası kast edilmiş olur.

İhtiyaç halinde söylenmesi, yerine göre ifade edilmesi, ne çok kısa ne de çok uzun olması, cümle ve ifade tarzlarının titizlikle seçilmesi şeklinde söz için dört şart sıralayan Mâverdî’nin (öl. 450/1058) bu açıklamalarından sözün gelişi güzel söylenmemesi gerektiği anlaşılmaktadır. ${ }^{18}$ Ayrıca teşbih, mecaz ve istiare gibi edebî sanatlarla bezenmiş olması kadar tutarlı, ölçülü ve seviyeli olmasına da özen gösterilmesi istenmektedir.

Burada güzel sözün muhataplar nezdindeki etkisi ve kıymetine binâen söz-sükût mukâyesesinde tercihini bariz bir şekilde sözden yana kullananların yaklaşımlarını da aktarmak uygun bir adım olacaktır. Söz-sükût mukâyesesi bağlamında ilk olarak göze çarpan muallaka şairlerinden Züheyr b. Ebî Sülmâ'nın (öl. 609 [?]) aşağıda yer verilen şu beyitleridir:

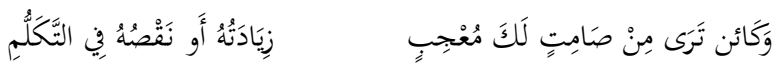

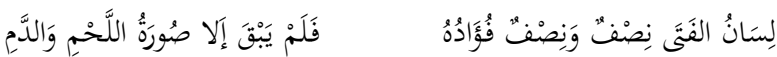

Dikkatini çeken nice suskun görürsün;

Fazlalı̆̆l ya da noksanlığı (belli olur) konuşmasında.

Kişinin dili (onun) yarısıdır, diğer yarısı da kalbidir,

13 Ebû Abdillâh Muhammed b. İdrîs b. Abbâs eş-Şâfî̂, Dîvânu'l-Imâmi'ş-Şâfi 'î, haz. Ömer et-Tebbâ‘ (Beyrut: Dâru'l-Erkam bin Ebi'l-Erkam, 1416/1995), 99.

14 Ebü'l-Hâris Zürrumme Gaylân b. Ukbe b. Ma'dî b. Amr el-Kahtânî, Dîvânu Zürrumme, haz. Ahmed Hasan Besec (Beyrut: Dâru'l-Kutubi'l-İlmiyye, 1415/1995), 104; Şâfî̂, Dî̀ânu'l-İmâmi'ş-Şâfi 'î, 114.

15 Ebü'l-Velîd Hassân b. Sâbit b. el-Münzir el-Ensârî, Dîvânu Hassân b. Sâbit, thk. Abede Mühennâ (Beyrut: Dâru'l-Kutubi'l-İlmiyye, 1414/1994), 81; Yemân b. Ebi'l-Yemân el-Bendenîcî. et-Takfiyye fi'l-luğa, thk. Halil İbrahim el-Atiyye (Bağdad: Matbaatu'l-Ânî, 1976), 335.

16 Husrî, Zehrü'l-âdâb ve semerü'l-elbâb, 1/50; Ebü'l-Meâlî Bahâüddîn Muhammed b. el-Hasen b. Muhammed b. Alî b. Hamdûn, et-Tezkiretü'l-Hamdûniyye, thk. İhsan Abbas - Bekir Abbas (Beyrut: Dâru Sâdır, 1996), 5/404.

17 İbn Hamdûn, et-Tezkiretü'l-Hamdûniyye, 5/404.

18 Ebü'l-Hasen Alî b. Muhammed b. Habîb el-Basrî el-Mâverdî, Edebü'd-dünyâ ve'd-dîn, haz. Komisyon (Beyrut: Dâru'l-Minhâc, 1434/2013), 443. 


\section{Böylece geriye bir şey kalmaz et ve kan dışında. ${ }^{19}$}

Züheyr, söylenilen sözler karşısında edebiyle suskunluğunu koruyanlara karşı bir hayranlık duyulabileceğini kabul eder ama ona göre bir kişinin asıl değeri ve karakteristik yapısı doğrudan konuşmasıyla irtibatlıdır. ${ }^{20} \mathrm{Bu}$ durumda Züheyr'e göre güzel ve etkili konuşma mükemmel bir dinleyici olmanın ötesinde bir şeydir. Aslında onun bu beyitlerinde altını çizdiği husus, Arap toplumu tarafından dillendirilen إنَّما إمرٔم

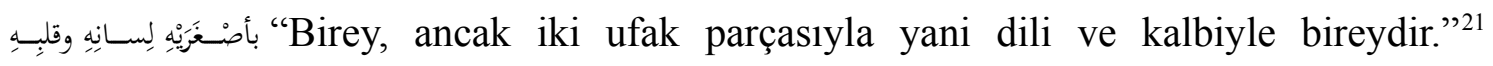
cümlesiyle de vurgulanmaya çalışılmıştır.

Öte yandan söz ve sükûttan hangisinin daha üstün olduğuna ilişkin klasik dönem ilim meclislerinde cereyan eden diyaloglara bakıldığında özellikle fakih, muhaddis veya mutasavvıf kimliği daha ağır basan şahsiyetlerin sükûtu söze, edebî kimliği ön plana çıkan bireylerin ise sözü sükûta tercih ettikleri görülmektedir. Bahse konu olan meseleye temas edenlerden Câhiz (öl. 255/869) karşıt sayılabilecek çeşitli görüşleri aktardıktan sonra şöyle der: “Faydası (kimi zaman) umumi (kimi zaman) hususi olan söze, yararı sahibinden öteye geçmeyen sükût tercih edilip ondan daha faydalı görülebilir mi? Râviler (öteden beri) sükût edenlerin sessizliğini değil konuşanların sözlerini ve ifadelerini aktarmışlardır. Yüce Allah (c.c.) peygamberleri sükût etmek için değil konuşmak için göndermiştir. (Öte yandan) sükûtun övülmeye değer görüldüğü

19 Züheyr b. Ebî Sülmâ (Rebîa) b. Riyâh el-Müzenî, Dîvânu Züheyr b. Ebû Sülmâ, haz. Ali Hasan Fâur (Beyrut: Dâru'l-Kutubi'l-İlmiyye, 1408/1988), 111, 112.

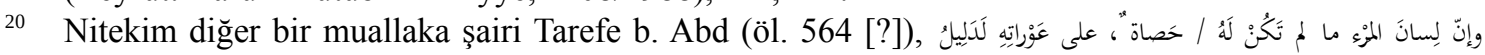
“Mantık olmadı̆̆ında, kişinin dili onun kusurlarına bir delildir.” deyip akıl süzgecinden geçirilmeyen konuşmaların insanın kişilik yapısını ortaya çıkardığını belirtmektedir. bkz. Ebû Amr Tarafe b. el-Abd b. Süfyân b. Sa'd el-Bekrî, Dîvânu Tarafe b. el-'Abd, haz. Mehdi Muhammed Nâsırüddîn (Beyrut: Dâru'l-Kutubi'l-İlmiyye, 1423/2002), 67; Ebü'l-Haccâc Yûsuf b. Süleymân b. Îsâ el-A'lem eşŞentemerî, Dîvânü Tarafe b. el- 'Abd Şerḥu'l-A 'lem eş-Şentemerî, nşr. Dürriyye el-Hatîb - Lutfî esSakkal (Beyrut: el-Müessesetü'l-Arabiyye li'd-Dirâsât ve'n-Neşr, ts.), 92.

21 Ebû Ömer Cemâlüddîn Yûsuf b. Abdillâh b. Muhammed İbn Abdilberr en-Nemerî, Behcetü'l-mecâlis ve ünsü'l-mücâlis ve şaḩzü'z-żâhini ve'l-hâcis, thk. Muhammed Mürsî el-Hûlî (Beyrut: Dâru'lKutubi'l-İlmiyye, 1402/1982), 1/55; Abdullah b. Abdilazîz b. Muhammed b. Eyyûb b. Amr el-Bekrî, Fașlü'l-maḳâl fí şerḥi Kitâbi'l-Emșâl, thk. İhsan Abbas - Abdülmecid Âbidîn (Beyrut: Müessesetü'rRisâle,1391/ 1971), 136, 137. 
yerler az, sözün ise çok fazladır. (Zaten) uzun süreli bir sükût dili (cümle akışını) bozar."22

Câhiz’in bu yaklaşımı bazı edebî eserlerde yer alan şu dizelerde de karşımıza çıkmaktadır:

$$
\text { خلحلقَ اللسانَ لِنُطْقِهِ وبيانِنِ }
$$

Allah, konuşma ve açıklama için yaratmıştır dili;

Sükût için değil, (zaten) sükût kaderidir dilsizin.

(Bir yere) oturduğunda cevap veren, soru soran ol!

Zira söz güzelleştiriyor sahibi olduğun meclisin. ${ }^{23}$

Kûfe dil mektebinin önemli temsilcilerinden Sa‘leb lakaplı Ebü’l-Abbâs Ahmed b. Yahyâ b. Zeyd'e (öl. 291/904) nispet edilen ve inanç merkezli bir yaklaşımla dillendirilen aşağıdaki beyitler onun da tıpkı Câhiz gibi söz-sükût arasında net bir ayrıma giderek sözü sükûta tercih ettiğini göstermektedir:

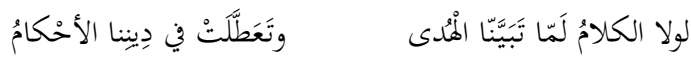

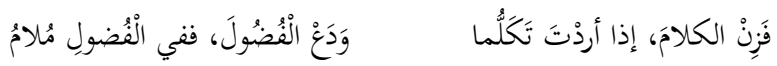

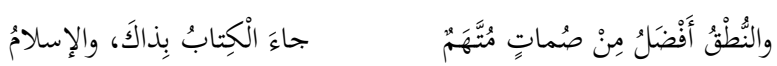

Doğru yolu açıklayamazdık söz olmasaydl;

Atıl kalırdı dinimizin ahkâmları

Konuşmak istediğinde sözünü tart;

Bıkkınlık verdiği için terk et fazlalıkları.

Konuşma, töhmetli suskunluktan iyidir;

22 Câhiz el-Beyân ve't-tebyîn, 1/272. Daha çok farklı görüş ve eleştirileriyle ön plana çıkan Selefî âlim İbn Teymiyye (öl. 728/1328) فالتكلم بالخير خير من السكوت عنه، والصمت عن الشر خير من التكم به به "Hayra yönelik konuşmak ondan sükût etmekten, şerre yönelik sükût (da) ondan konuşmaktan daha iyidir." diyerek gerek söz gerekse sükûtu iyi-kötü ekseninde değerlendirmiştir. bk. Ebü'l-Abbâs Takıyyüddîn Ahmed b. Abdilhalîm b. Mecdiddîn İbn Teymiyye, Mecmû'u fetâvâ, nşr. Abdurrahman b. Muhammed b. Kasım (Medine: Mücemmeü'l-Melik Fehd li't-Tabbâati'l-Mushafi'ş-Şerîf, 1425/2004), 11/200.

23 Ebü'l-Kāsım Hüseyn b. Muhammed b. el-Mufaddal er-Râgıb el-İ̀sfahânî, Muhâdarâtü 'l-üdebâa' ve muhâverâtü' 'ş-şu 'arâ' ve 'l-büleg̀ga' ', haz. İbrahim Zeydân (Misır: Mektebetü'l-Hilâl, 1902), 31. 
Kur'ân ve İslâm getirmiştir bunlart. ${ }^{24}$

Bazı kaynaklarda yer alan "Şüphesiz ki dilin hareketliliği artarsa tatlılığı da zariflik kazanır.” açıklaması konuşkan bir dilin zamanla daha da açılacağı ve daha güzel ifadeler geliştireceğini ön görmektedir. ${ }^{25}$ Aynı şekilde Abbasî dönemi hatip ve kâtiplerinden Attâbî’ye (öl. 220/835) nispet edilen “Eğer dil işlevinden engellenirse harflerin mahreçlerini çıkartmada zorluk çeker." ${ }^{26}$ şeklindeki tespit, dilin uzun bir müddet hareketsiz bırakılmamasını ögütlemektedir ki bu açıklamalardan sözün sükûta tercih edilmesi gerektiği anlaşılmaktadır.

Elbette ki bazı sözler onur kırıcı ve aşağılayıcıdır ve bu gibi durumlarda suç dilde değil dilin sahibindedir. Eğer bazen sükût söze tercih edilmişse de bu lüzumsuz konuşmalara hasredilmiş ${ }^{27}$ ya da kişinin kendisini veya yakınlarını tehlikeye atma olasılığı üzerinden okunmuştur. Nitekim bu durum klasik Arap şiiri ve deyimlerde sıklıkla dile getirilmiştir. ${ }^{28}$ Kaldı ki dil yarasının kesici alet yaralarından daha ağır olduğuna ilişkin ileri sürülen görüşlerin tümünde dolaylı olarak güzel ve tatlı sözün önemi vurgulanmak istenmiştir. Kısacası dil, sahibinin ilmi kapasitesi, ahlaki eğitimi ve olgunluk düzeyiyle doğrudan ilişkili olduğu için güzel kullanıldığında güzel, kötü kullanıldığında ise kötü sonuçlara neden olabilmektedir. Mevzubahis edilen konunun en dikkat çekici örneği dil âlimi ve ahlâk felsefecisi er-Râgıb el-İsfahânî’nin (öl. 5./11. yüzyılın ilk çeyreği) naklettiği şu rivayettir: "Lokman Hekîm, kesilmiş bir hayvanın en güzel ve en kötü parçasını isteyen efendisine hayvanın dilini götürmüş, güzel olduğu zaman bundan daha güzeli, kötü olduğu zaman da bundan daha kötüsü yoktur” demiştir. $^{29}$

${ }^{24}$ Ebü't-Tayyib Muhammed b. Ahmed b. İshâk b. Yahyâ el-Veşşâ', Kitâbü'l-Müveşşâ: ez-Zarf ve'zzurefâ', thk. Kemal Mustafa (Misır: Mektebetü'l-Hânecî, 1372/1953), 11.

25 Ebü’l-Abbâs Muhammed b. Yezîd b. Abdilekber el-Müberred, el-Kâmil fi'l-edeb, thk. Muhammed Ahmed ed-Dâlî (Beyrut: Müessesetü'r-Risâle, 1412/1992), 1/532.

26 İbn Abdirabbih, el- 'ịkdü'l-ferîd, 2/307.

27 İbn Abdilberr en-Nemerî, Behcetü'l-mecâlis, 1/60-63.

28 Şâfiî, Dîvânu'l-İmâmi'ş-Şâfi 'î, 116; Ebû Ubâde el-Velîd b. Ubeyd et-Tâî Buhtürî, el-Hamâse, haz. Kamil Mustafa (Kahire: el-Matbaatü'r-Rahmaniyye, 1929), 401-405; Ebû Ubeyd el-Bekrî, Fașlü'lmakāl fì șerhi Kitâbi'l-Emșâl, 21-25.

29 Râgıb el-İsfahânî, Muhậ̣̂arâtü'l-üdebâ', 32. 


\section{Klasik Arap Şiirinde Güzel Sözün Benzetildiği Unsurlar}

İçinde hoşgörü, samimiyet ve zarafet barındıran bir sözün muhataplarının iç dünyasında daha fazla etkili olacağı inkâr edilemez. Nitekim İslâmî literatürde güzel ve tatlı söz sahibi insanların mükâfatlandırılacağı bildirilmekte ve bu güzel davranışın yaygınlaştırılması temel hedefler arasında gösterilmektedir. Örneğin Hz. Peygamber

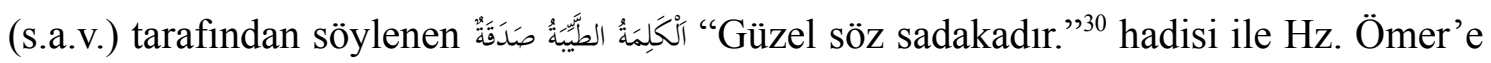

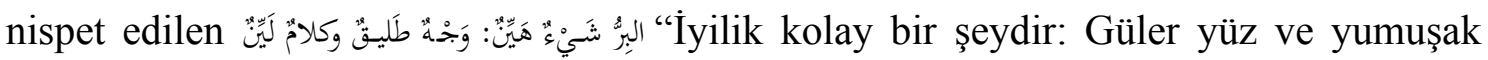
sözdür."’31 ifadesi bir yandan güzel konuşmanın karş1lıksız kalmayacağını öğütlerken diğer yandan güzel söz söylemeyi doğrudan teşvik etmektedir.

Hz. Peygamber’in ünlü şairlerinden Kâ‘b b. Mâlik el-Ensârî’nin (öl. 50/670)

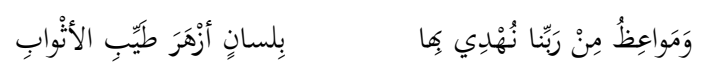

(Insanlarl) Rabbimizden (gelen) bazı ögütlerle,

Çiçek ve tertemiz elbise gibi olan bir dille doğru yola iletiyoruz. ${ }^{32}$

beytinde dilin estetik boyutu ve iffetine dikkat çekilerek insanların ancak bu şekilde hidayet bulabileceğine vurgu yapılmıştır.

Aslında güzel ve estetik sözler dinî ve kültürel değerlerle yoğrulmuş anlamlar üzerinden tespit edilebilir. Bununla birlikte özellikle benzetilen unsurlar açısından iyikötü, güzel-çirkin, seviyeli-seviyesiz, etik veya netice odaklı olduğuna ilişkin bir kanaate de varılabilir. Zira teşbih sanatı anlatımı güçlendirdiği gibi iki varlık arasındaki ortak niteliği de belirgin kılar. Binaenaleyh eğer bir söz güzel, büyüleyici ve değerli addedilen şeylere benzetilmişse bu durumda asıl hedefi en güzeli ortaya koymak olan

30 Ebû Abdillâh Muhammed b. İsmâîl b. İbrâhîm el-Buhârî, el-Câmi 'u'ṣ-ṣahîhh (Lübnân: Dâru't-Te'sîl, 1433/2013), "Edeb", 34 (No: 6028).

31 Ebû Bekr Abdullah b. Muhammed b. Ubeyd İbn Ebü'd-Dünyâ, Kitâbu'ș-Sumt ve âdâbü'l-lisân, thk. Necm Abdurrahman Halef (Beyrut: Dâru'l-Garbi'l-İslâmî,1406/1986), 397; Ebü'l-Ferec Zeynüddîn Abdurrahmân b. Ahmed b. Abdirrahmân İbn Receb, Lețâ'ifü'l-ma 'ârif fìmâ li-mevâsimi'l- 'âm mine 'l-vezâ 'if, thk. Yasin Muhammed es-Sevvâs (Beyrut: Dâru İbn Kesîr, 1420/1999), 410.

32 Ebû Abdillâh Kâ‘b b. Mâlik b. Ebî Kâ‘b Amr el-Ensârî, Dîvânu Ka'b b. Mâlik el-Enșârî, thk. Sâmî Mekkî el-Ânî (Bağdad: Mektebetü’l-Maârif, 1386/ 1966), 181. 
edebî sanat ile onun en önemli malzemesi sayılan dilin gerçek görevi arasında tam bir örtüşme sağlanmış demektir.

Klasik Arap edebiyatında güzel söze dair beyitler genel başlık sayılabilecek medih (övgü), hiciv (yergi), doğa tasviri, gazel, hikemiyât, zühdiyyât, fahr (gurur), i'tizâr ve isti ‘tâf (teveccüh) ve risâ, (ağıt) temaları içerisinde daha çok medih ve gazel kategorileri altında göze çarpmaktadır. Benzetildiği unsurlar arasında ise sihir, rengârenk bahçeler, bal, değerli taşlar ve güvercin gerdanlığı birden fazla şair tarafından dillendirildiği için sadece bu unsurlar alt başlıklar şeklinde ele alınmıştır.

\subsection{Sihre Benzetilmesi}

Güzel sözü sihre benzetenler, muhatabı etkisi altına alan ve onu kolayca ikna edebilen büyülü ifadeleri kast ederler. Bu yönde bir benzetme yapan ilk kişi $\mathrm{Hz}$. Peygamber’dir (s.a.v.). İmam Buhârî’nin (öl. 256/870) aktardığına göre Medine’nin doğu taraflarından gelen iki kişi halka hitap ettikten sonra halk bu kişilerin konuşmalarına hayran kalmış ve bu hadise sonrasında Hz. Peygamber "Şüphesiz bazı ifadeler gerçekten de sihirdir.” şeklinde bir açıklamada bulunmuştur. ${ }^{33}$ Sihrin yaldızlı sözler söyleme aracılığıyla göz boyama ve aldatma yönünün olması hasebiyle ilgili hadiste insanları hayran bırakacak sözlerin sihre benzetilmesini olumsuz anlamda değerlendirenler olmuştur; ancak özellikle belagatçılar, edebî sanatları haiz, açık ve anlaşılır bir sözün sihre benzetilmesine olumlu bakmışlardır. ${ }^{34}$ Bazı edebî eserlerde yer alan “Güzel söz düğüm üfürüklerinden birisidir.” açıklaması da belagatçıların bu olumlu yaklaşımlarında haklı olduklarını göstermektedir. ${ }^{35}$

Güzel sözü sihre benzeten şairlerden Beşşâr b. Bürd el-Ukaylî (öl. 167/783-84)

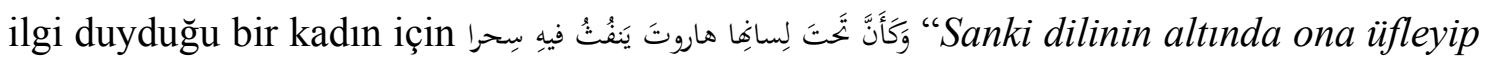
büyülü kılan Hârût vardır." ${ }^{36}$ diyerek insanlara büyü yapmayı öğreten iki melekten biri olan Hârût ismini zikretmiş ve mahbubunun fiziki özellikleri yerine sözlerindeki

33 Buhârî, “Tıb”, 48 (No: 5767).

34 Ebû Hilâl el-Hasen b. Abdillâh b. Sehl el-Askerî, Cemheretü'l-emsâal, thk. Muhammed Ebü'l-Fazl İbrâhim - Abdülmecid Katâmiş (Beyrut: Dâru'l-Cîl, 1408/1988), 1/13, 14.

35 Husrî, Zehrü'l-âdâb ve semerü'l-elbâb, 1/29; İbn Hamdûn, et-Tezkiretü'l-Hamdûniyye, 5/402.

36 Ebû Muâz Beşşâr b. Bürd el-Ukaylî, Dîvânu Şi 'ri Beşşâr b. Bürd, thk. Bedreddin el-Alevî (Beyrut: Dâru's-Sekâfe, 1981), 118. Câhiz, el-Beyân ve't-tebyîn, 1/276. 
büyüleyici güzelliği anlatmayı tercih etmiştir. Zira kimi şairlerin de işaret ettiği gibi dil, dış görünüşe bakılmadan birisinin yerilmesi veya övülmesi noktasında kabul edilebilir bir kistastır. ${ }^{37}$

Şair Ebû Temmâm’ın (öl. 231/846) Ebû Said Muhammed b. Yûsuf et-Tâîyi kast ederek sarf ettiği şu dizelerde de sihre atıf yapılmıştır:

$$
\begin{aligned}
& \text { فأينَ قصائدُ لِ فيك تأبى وتأنَفُ أنْ أُهانَ وأنْ أُذالا }
\end{aligned}
$$

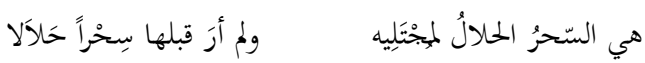

Seninle alakall kasidelerim nerede?

Suçlanıp küçük düşürüleceğimi engelleyecek.

O kasideler, dikkatli bakanlar için helal sihirdir;

Ben helal sihir görmedim şimdiye dek. ${ }^{38}$

Güzel sözü sihre benzeten diğer bir şair daha çok hicivleriyle tanınan İbnü'rRûmî’dir (öl. 283/896). Kendisi bir kadının sözlerini nitelerken وحَديُُها السحرُ الحلالُ لو أنّهُ / لمَمَيْنِ

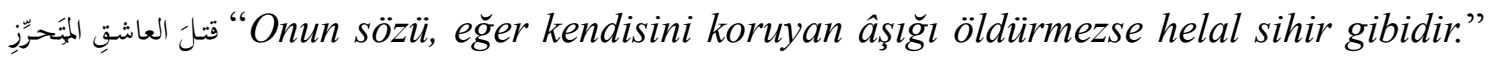
diyerek nitelediği kadının sözlerinden temkinli ve aklı başında bir âşı̆̆ın bile etkilenebileceğini söyler. Devamında Eğger uzun konuşursa bıkkınlık vermez, veciz konuştuğu zaman ise dinleyici kısa kesmemesini arzular." 39 diyen İbnü’r-Rûmî nitelediği kadının, düşünülenin aksine uzun konuşmasının dinleyenlerin ilgisini daha fazla çektiğini de ifade eder.

Kimi edip ve şairlerin güzel sözü sihre benzettikten sonra özellikle helal nitelemesini kullanmaları İslâmî öğretilerde sihrin net bir dille yasaklanmasından kaynaklanmaktadır. ${ }^{40}$ Böylece onlar muhabbet duydukları kişilerin büyüleyici ve gönül çelici sözlerini, paranormal yöntemlerle kandırma, aldatma, göz boyama ve yaldızlı

37 Müberred, el-Kâmil fi'l-edeb, 2/652; Mâverdî, Edebü'd-dünyâ ve'd-dîn, 443.

38 Husrî, Zehrü'l-âdâb ve semerü'l-elbâb, 1/30.

39 Ebü'l-Hasen es-Serî b. Ahmed b. es-Serî er-Reffâ', el-Muhib ve'l-mahbûb ve 'l-meşmûm ve'l-meşrûb, thk. Teiletion von Misbâh Galâvuncî (Dımaşk: Matbûâtu Macmai'l-Lügati'l-Arabiyye, 1407/1986), 1/159; Ebû Hilâl el-Hasen b. Abdillâh b. Sehl el-Askerî, Dîvânü 'l-me 'ânî, thk. Ahmed Selim Gânim ( b.y: Dâru'l-Garbi'l-İslâmî, 1424/2003), 1/483; Husrî, Zehrü'l-âdâb ve semerü'l-elbâb, 1/32.

40 Sihrin kesin bir şekilde yasaklandığına ilişkin bkz. Buhârî, “Tıb”, 48 (No. 5764). 
sözlerle oyalama şeklinde ${ }^{41}$ doğa kanunlarına aykırı olan vakalara gerçek görüntüsü kazandırıp kendi emellerine ulaşmaya çalışanların sözlerinden ayrı tutmaya çalışmışlardır.

\subsection{Güzel Bahçelere Benzetilmesi}

Her şairin doğadan ilham alarak şiir yazdığı muhakkaktır hatta bazı şairler sadece doğa tasvirleriyle ön plana çıkmışlardır. Çiçekler, çeşitli çimler, çalılar ve farklı ağaç türleriyle yeşilin her tonunu içinde barındıran bahçeler ise doğanın güzelliğini yansitan en görkemli alanlardan sayılır. Bu yüzden kimi şairler güzel sözü hoş manzaralı bahçelere benzetmişlerdir. Örneğin Câhiliye dönemi şairlerinden Cirân el-

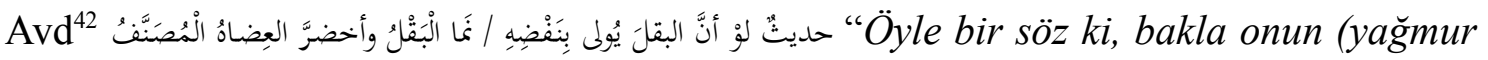
gibi) serpmeleriyle sulansa yetişecek ve kurumuş dikenli çall (da) yeşerecek." "43 manasına gelen bu beytinde kurumaya yüz tutmuş bir yerin yağmur suyuyla can bulup yemyeşil bir mekana dönüşmesinden sonraki hali ile güzel söz arasında bir bağ kurmaya çalışmıştır.

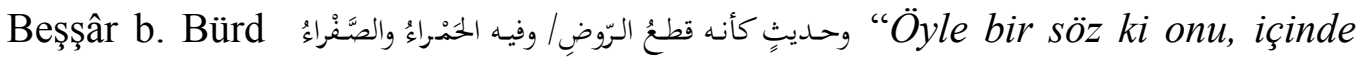

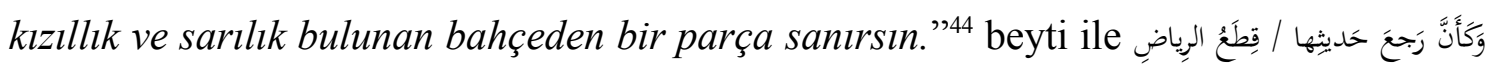
" كُســنَ زَهـرا 'Onun sözünün yankısı (geri dönüşü) çiçeklerle bürünmüş bahçeden bir parçadır." ${ }^{45}$ beytinde ağızdan çıkan sözleri sadece bahçelere benzetmekle kalmayıp bahçeleri ayrıca çiçeklerle birlikte zikrederek adeta güzellikler içindeki bir güzelliği ve narinliği nitelemiştir. Beşşâr b. Bürd'ün, "Hazırlandı̆̆ından dolayı göz çukurları siyahlaşmış olan var ya! Onun sözleri bahçelerdeki meyveler gibidir.” manasına gelen 的 ${ }^{46}$ beytinde de bu yönde bir teşbih göze çarpmaktadır.

41 Gülay Karaman, Klasik Türk Edebiyatında Sihir (Kocaeli: Kocaeli Üniversitesi, Sosyal Bilimler Enstitüsü, Doktora Tezi, 2015), 33, 34.

42 İlgili kaynaklara müracaat edilmiş fakat şairin kesin vefat tarihine yönelik bir bilgiye rastlanmamıştır.

43 Âmir b. el-Hâris en-Nümeyrî Cirân el-Avd, Dîvânu Cîrân el-'Avd en-Nümeyrî, haz. Ahmed Nesim (Kahire: Matbaatu Dâri'l-Kutubi’l-Misriyye, 2000), 21. Câhiz el-Beyân ve't-tebyîn, 1/281.

44 Beşşâr b. Bürd, Dîvânu Şi 'ri Beşşâr b. Bürd, 11; Câhiz, el-Beyân ve't-tebyîn, 1/277.

45 Beşşâr b. Bürd, Dîvânu Şi 'ri Beşşâr b. Bürd, 118.

46 Beşşâr b. Bürd, Dîvânu Şi 'ri Beşşâr b. Bürd, 235; Husrî, Zehrü’l-âdâb ve șemerü'l-elbâb, 1/43. 
Güzel söz ve bahçeleri yan yana getirip kişileştirme sanatı doğrultusunda bir örnek sunan Abbâsî dönemi şairlerinden Ebü’t-Tayyib el-Mütenebbî (öl. 354/965) وذكيّ

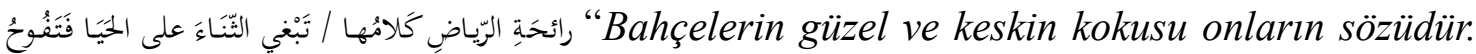
Yağmuru övmek istediklerinde kokarlar." ${ }^{\text {47 }}$ beytinde doğrudan güzel sözü bahçelere benzetmemişse de etrafa yaydıkları güzel kokularıyla yağmur bulutlarına teşekkür ettiklerini söyleyerek aslında bahçelerden etrafa yayılan bu kokuların bir tür söz olduğuna dikkat çekmiştir. ${ }^{48}$

Arap nesîr sanatının usta kalemlerinden Ebû Hayyân et-Tevhîdî’nin (öl. 414/1023), aktardığına göre şair Ebü’l-Aynâ (öl. 283/896) İbnü’l-Mukaffâ’nın (öl.

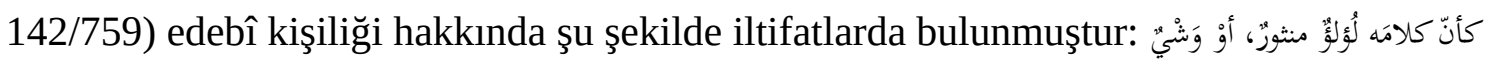
"Onun sözü etrafa saçllmış bir inci veya süslemeli bir kumaş ya da bol yağmur almış bir bahçe gibiydi."49 Ebü’l-Aynâ, İbnü’l-Mukaffâ'nın ağzından çıkan sözlerin her bir kelimesinin anlamlı olduğu kadar kıymetli olduğuna değerli taşlar üzerinden işaret etmiştir. Cümlelerin birbiriyle olan ahenk ve insicamını vurgulamak için işlenmiş bir kumaşı örnek veren Ebü’l-Aynâ yeteri düzeyde yağmur suyu almış bir bahçeden de söz ederek aslında mantıklı, güzel ve etkileyici bir dilin yemyeşil manzarasına doyum olmayan bahçeler gibi huzur kaynağı olabileceğini anlatmaya çalışmıştır.

Gerçekten de doğa özlemi ve sevgisinin bir müsebbibi olarak öteden beri var olan ya da insan eliyle oluşturulan bahçeler gerek barındırdığı çeşitli ağaç, çiçek ve bitkilerin muhteşem manzarası, gerek etrafa yaydığ 1 güzel koku, gerekse ruha dinginlik veren yeşilliğiyle birçok edip ve şairin ilham kaynağı olmuştur. Öyle ki Sanevberî (öl. 334/945-46) gibi bazı şairler neredeyse tüm kasidelerini sadece bahçe ve çiçek

47 Ebü’t-Tayyib Ahmed b. el-Hüseyn b. el-Hasen el-Mütenebbî, Dîvânü'l-Mütenebbî (Beyrut: Dâru Beyrut, 1403/1983), 69.

48 Ebü’l-Bekā Muhibbüddîn Abdullāh b. el-Hüseyn b. Abdillâh el-Ukberî, et-Tibyân fì şerhii'd-Dîvân Şerḥu Dîvâni'l-Mütenebbî, nşr. Mustafa es-Sekkā vd. (Beyrut: Dâru'l-Marife, ts ), 1/255.

49 Ebû̀ Hayyân Alî b. Muhammed b. Abbas et-Tevhîdî, el-Beșấir ve'ż-zehẩir, thk. Vedat el-Kâdî (Beyrut: Dâru Sâdır, 1408/1988), 8/54. 
tasvirlerine hasretmişlerdir. ${ }^{50}$ Hatta Sanevberî’nin kasidelerindeki bahçe ve çiçek tasvirlerinin çoğunluğunu göz önünde bulundurup الروضيات başlığıyla eser yazanlar bile olmuştur. ${ }^{51}$

Bulundukları alanların bir nevi nefesi olan güzel ve gönül ferahlatıcı yemyeşil bahçeler kimi şairlerin şiirlerinde benzeyen unsur olarak da yer almaktadır. Örneğin Sanevberî’nin muasırı olan Küşâcim lakaplı Ebü'l-Feth Mahmûd b. el-Hüseyn es-Sindî (öl. 360/971), Mısır hakkında yazdığı kasidesinde göz kamaştırıcı bahçeler ile rengârenk

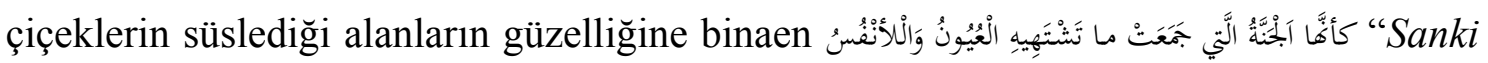
Mısır, gözlerin ve gönüllerin iştah duyduğu/arzuladı̆̆ı (gerçek) Cennet'tir." şeklinde bir ifade kullanarak muhteşem manzaralı bahçelere sahip olan Mısır diyarını ahiretteki cennete benzetmiştir. ${ }^{52}$

\subsection{Bala Benzetilmesi}

Arap dili ve edebiyatı âlimi Ebû Hilâl el-Askerî’nin (öl. 400/1009) “Tüm insanlar sözün tatlığını balın tatlılığına benzetir.”53 şeklindeki açıklamasından da anlaşılacağı üzere halk arasında bu denli yaygın olan bir benzetmeye edip ve şairler de kayıtsız kalmamışlardır. Nitekim klasik Arap edebiyatında muhatabın ruhuna etki edecek yumuşak ve kulağa hoş gelen sözlerin güzelliğine yönelik kasideler yazılmış ve bu kasidelerin bazı beyitlerinde güzel sözler, tatlılığının yanı sıra hasta bedenlerin şifa kaynağı olarak da bilinen bala benzetilmiştir. Örneğin Muhadram şairlerden Ebû Züeyb el-Hüzelî (öl. 28/648-49) 23 beyitlik kasidesinin ilgili pasajında muhabbet beslediği kadının sözlerini sütle karıştırılmış bala benzeterek şöyle der:

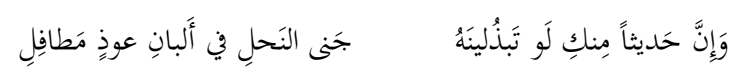

Senden gelen bir söz (etrafa) yayıldı̆̆ında, sanki o,

\footnotetext{
50 Nasuhi Ünal Karaarslan, "Sanevberî”, Türkiye Diyanet Vakfi İslâm Ansiklopedisi (Erişim 6 Ekim 2021).

51 Fidâ Muhammed Ganim, “eț-Ṭabî‘atü’l-mâiye fî̀ şi'ri'ṣ- Șanevberî”, Mecelletü'l-Belkâ' li’l-Buhûs ve'd-Dirâsât, 17/1 (2014), 83.

52 Ebü'l-Feth Mahmûd b. el-Hüseyn b. es-Sindî b. Şâhek, Dîvânu Küşâcim, thk. Nebevî Abdülvâhid Şa'lân (Kahire: Mektebetü'l-Hânecî, 1417/1997), 225.

53 Ebû Hilâl el-Askerî, Dîvânü'l-me 'ânî, 1/483.
} 
Develerin sütüne karıştırılmış bal arısının mahsulüdür. ${ }^{54}$

Emevîler devrinde tabiat tasvirleriyle öne çıkan şair Ebü’l-Hâris Zürrumme Gaylân b. Ukbe el-Kahtânî (öl. 117/735) de karşılaştığı bir dostuyla aralarında geçen samimi konuşmayı, kaynağından süzülen berrak bir suyla karıştırılmış olan bala benzetmiş ve şöyle demiştir:

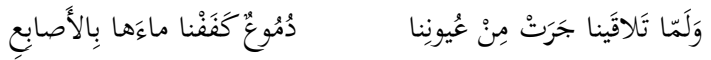

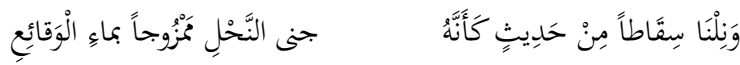

Seninle karşılaştı̆̆ımızda akıyordu gözlerimizden

Parmaklarımızla sildiğimiz yaşlar.

Öyle bir konuşmaya daldık ki sanki o,

Zirvelerden akan suyla karıştırılmış bir bal. ${ }^{55}$

Diğer bir şair حســ "Bö söz ki göz nazarından korkmazsan ĕger, sanki o baldır ya da baldan daha hoştur." لو أنك تستشفي به بعد سكَكْة / من الموت derinliklerine işleyen cümleleri baldan daha tatl1 görmüş ve "Eğer ölüm sarhoşluğundan/hastalı̆̆ından sonra onun ile şifa dilersen neredeyse bu sarhoşluk yok olacaktır." ${ }^{57}$ şeklindeki betimlemesiyle güzel sözlerin gönüllerde bıraktığı etkiyi ölüm anındaki hastalığın bile şifası sayarak oldukça mübalağalı ifadelere başvurmuştur.

Arap edebiyatının meşhur nesir yazarlarından Câhiz'in Hakem b. Reyhân’a nispet ettiği beytiler ile Büveyhî veziri edip ve şair Ebü’l-Kāsım İsmâîl b. Abbâd b. elAbbâs’ın (öl. 385/995) kulağa hoş gelen anlamlı yazı ve cümleleri övdüğü dizeleri de bu bağlamda zikredilmeye değerdir:

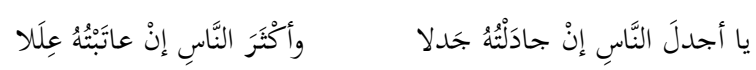

54 Ebû Züeyb Huveylid b. Hâlid b. Muharris el-Hüzelî, Dîvâanu Ebî Zü̈'eyb el-Hüzelî, thk. Ahmed Halîl eş-Şâl (Port Said: Merkezü'd-Dirâsât ve'l-Buhûsi'l-İslâmiyye, 1435/2014), 86; Câhiz el-Beyân ve'ttebyîn, $1 / 278$.

55 Câhiz, el-Beyân ve't-tebyîn, 1/282; Ebû Zekeriyyâ Yahyâ b. Alî b. Muhammed el-Hatîb et-Tebrîzî, Şerhu Dîvâni Zirrumme (Beyrut: Dâru'l-Kitâbi'l-Arabî, 1416/1996), 276, 277.

56 Husrî, Zehrü'l-âdâb ve semerü'l-elbâb, 1/40.

57 Husrî, Zehrü'l-âdâb ve semerü'l-elbâb, 1/40. 


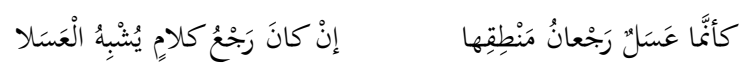

Ey kendisiyle mücadele ettiğimde herkesten daha mücadeleci

Ve azarladığımda bütün insanlardan daha dertli kişi!

Onun sözünün yankısı (geri dönüşü) sanki baldır;

(Tabi) ĕger bala benzetilecekse bir sözün geri dönüşü. ${ }^{58}$

İkinci beyitteki müennes ve gaibe zamirinden Hakem b. Reyhân’ın hitap ettiği kişinin kadın olduğu anlaşılmaktadır. Böylece şair, kadının mücadeleci bir karaktere sahip olduğunu söylemekte ve en ufak bir azarlamadan sonra onun bal gibi tatlı serzenişlerinden haber vermektedir.

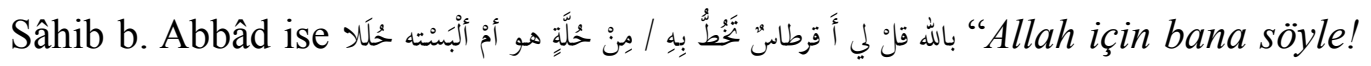
Kağıda kostümden mi yazı yazıyorsun? Yoksa (gerçekten de) ona kostüm mü giydirmişsin?" diyerek muhatabının kağıt ve üzerindeki ihtişamlı yazısı arasındaki

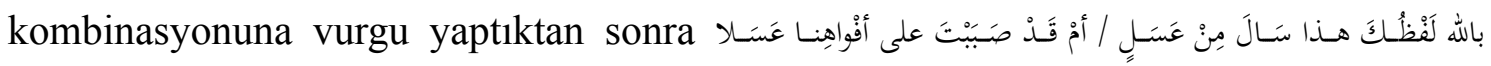
“Allah aşkına! Senin bu sözlerin baldan mı süzülüyor? Yoksa gerçekten de sen ă̆zımıza bal mı döktün?",59 şeklinde oldukça hoş ve gönül okşayıcı iltifatlarda bulunmuştur.

Dilin, kimi belagatçılar tarafından "Dil, onunla beyanın güzelliği ortaya çıkan bir araç, gönülde var olanı bildiren bir olgu, burada olmayandan haber veren bir tanık, kararı kesin bir hâkim, cevap veren bir sözcü, ihtiyacın karşılanmasını sağlayan bir arac1, hüznü bertaraf eden bir teselli, yabanlığı yok eden samimi bir dost, kötülükten sakındıran bir vaiz, iyiliğe çağıran bir dekoratör, sevgi eken bir çiftçi, garezin kökünü kurutan bir biçici, kulakların pasını silen bir eğlendiricidir." ${ }^{60}$ şeklindeki tanımı dikkate alındığında insan bedeninin en önemli organlarından olan bu et parçasına yüklenen asıl görevin, (toplumsal bir hayatın sürdürülebilirliğini kolaylaştırmak adına) güzellik ve tatlılık olduğu söylenebilir.

58 Câhiz el-Beyân ve't-tebyîn, 1/279.

59 Ebû Mansûr Abdülmelik b. Muhammed b. İsmâîl es-Seâlibî, Yetîmetü'd-dehr fî mehâasini ehli'l- 'așr, thk. Müfîd Muhammed Kumeyha (Beyrut: Dâru'l-Kutubi'l-İlmiyye, 1403/1983), 3/308.

60 Câhiz, el-Beyân ve't-tebyîn, 2/75; Ebû Bekr Abdülkāhir b. Abdirrahmân b. Muhammed el-Cürcânî, Delâ'ilü'l-i 'câz, nşr. Mahmûd Muhammed Şâkir (Kahire: Mektebetü'l-Hânecî, 1404/1984), 97; Ebü'l-Berekât Kemâlüddîn Abdurrahmân b. Muhammed el-Enbârî, Nüzhetü'l-elibbâ' fí tabakāti'lüdebâ', thk. İbrahim es-Sâmirâî (Ürdün: Mektebetü'l-Mennâr, 1405/1985), 149. 


\subsection{Değerli Taşlara Benzetilmesi}

Güzel, hoş ve tatlılık bakımından şairler tarafından sözün benzetildiği unsurlar arasında zümrüt, safir, elmas, yakut ve inci gibi değerli taşların bulunması dilin akla ve gönle hitap edebilme potansiyeline dolayısıyla da değerine doğrudan bir işarettir. Aslında Arapların sözlü kültüründe gerek güzel söz gerekse güzel yazının tek taşlı mücevhere (فرائـد الـدر) benzetilmesinin yaygınlığı darb-l mesel düzeyindedir. ${ }^{61}$ Sözlü kültürün devamını sağlama noktasında şairlerin üstlendiği rol ise hayatîdir. Dolayısıyla onlar hoşlandıkları ya da saygı duydukları kişilerin ağzından dökülen her ifade ve cümlenin yerli yerinde, anlamlı ve kıymetli olduğuna inci ve elmaslar üzerinden işaret etmişlerdir. Örneğin muallaka şairlerinden Antere (öl. 614 [?]) platonik aşk yaşadığı Able adlı sevgilisi için inşâd ettiği kasidesinin birinci ve ikinci beytinde lafzını altına, manasını da mücevhere benzettiği şu ifadeleri kullanmıştır:

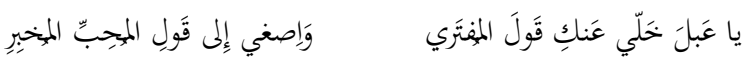

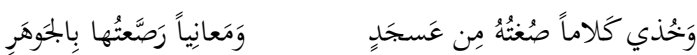

Ey Able! Müfterinin lafinı bir kenara bırak,

Seni sevip (doğru) bilgi verenin sözünü dinle.

Öyle bir kelamı al ki (lafzını) altın ile şekillendirmiş,

Anlamını ise (baştan aşağı) süslemişim cevherle. ${ }^{62}$

Aslında Antere, Able’ye yaptığı iltifatlarda doğrudan bir teşbih edâtı kullanmamıştır. Ancak nekra olarak kullandığg كعاني velimelerine fiil cümlesinden oluşan sıfatlar getirmiş, böylece kendi ifadelerinin lafız-anlam açısından altın ve mücevherden müteşekkil olduğunu söyleyerek onu etkilemeye çalışmıştır.

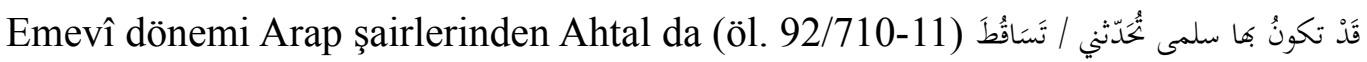
"Bazen Selma, ziynetleri dökülürcesine ihtiyaçlarımdan ve gizli

${ }_{61}$ Ebû Mansûr Abdülmelik b. Muhammed b. İsmâîl es-Seâlibî, Simârü'l-ḳulûb fi 'l-mużâf ve'l-mensûb, thk. Muhammed Ebü'l-Fazl İbrâhim (Beyrut: el-Mektebetü'l-Asriyye Seydâ, 1424/2003), 507.

62 Ebû Zekeriyyâ Yahya b. Alî b. Muhammed el-Hatîb et-Tebrîzî, Şerḥu Dîvâni 'Antere, nşr. Mecîd Tarrâd (Beyrut: Dâru'l-Kitâbi'l-Arabî, 1412/1992), 81. 
hallerimden konuşur." ${ }^{\text {63 }}$ derken muhabbet beslediği Selma adındaki kadının kendisine yönelik sözlerini bir gerdanlığa geçirilmiş olan inci ve elmasların etrafa saçılması durumuna benzetmiş ve onun bu ifadelerinin kendi nezdindeki değerine atıfta bulunmuştur.

Abbasi dönemi şairlerinden Selm b. Amr b. Hammâd el-Hâsir (öl. 186/802) ise övmeye çalıştığı kişinin gerek fiziksel olarak gerekse kitabet ve hitabet noktasında dikkatleri üzerine çektiğini belirterek onun kaleminden ve dilinden dökülen güzel ifadeler ile değerli taşlar arasında bir benzetme yapıp şu beyitlere yer vermiştir:

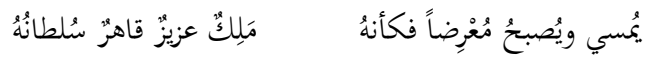

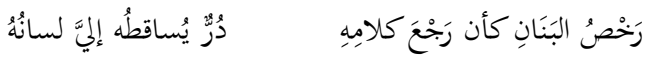

(Benden) yüz çevirerek akşamlayıp sabahllyor;

Zannedersin ki zorlayıcı ve güçlü bir kral.

Yumuşak parmaklıdır ve sanki sözlerinin yankısı

Diliyle üzerime döktüğ̈̈ elmaslar. ${ }^{64}$

Buhtürî lakaplı Ebû Ubâde el-Velîd b. Ubeyd b. Yahyâ et-Tâî (öl. 284/897)

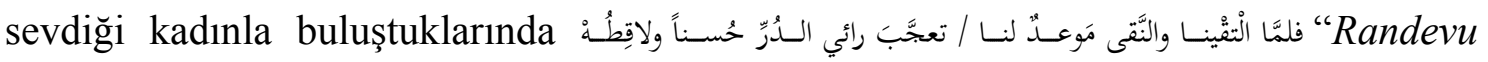
yerimiz en-Nekâ'da buluştuğumuzda / güzelliğinden dolayı incileri gören ve alan kişi hayran kaldı." ${ }^{65}$ mânasına gelen beytiyle onun hem dişlerini hem de dilinden dökülen

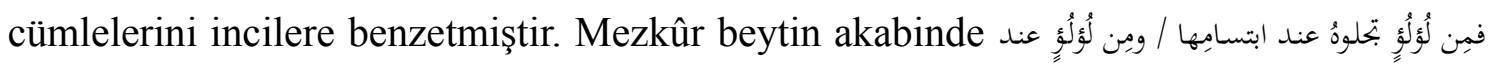
“Tebessüm ettiğinde net bir şekilde görünen (o) elmaslar / ve konuştuğu zaman (öylece) dökülen inciler." ${ }^{66}$ diyen Buhtürî kendisine methiyeler düzdüğü kadın

63 Ebû Saîd el-Hasen b. el-Hüseyn b. Ubeydillâh el-Atekî es-Sükkerî, Şi 'ru'l-Ahṭal, thk. Fahrettin Kabave (Dımaşk: Dâru'l-Fikr, 1416/1996), 123; İbn Kuteybe, 'Uyûnü'l-ahbâr, 4/82; Ebû Zeyd elKureşî, Cemheretü eş 'âri'l- 'Arab, thk. Ali Muhammed el-Bicâvî (Mısır: Dâru Nahdeti Misır, 1981), 719.

64 Serî er-Reffâ, el-Muhib ve'l-maḥbûb ve'l-meşmûm ve'l-meşrûb, 1/155, 156.

65 Ebû Ubâde el-Velîd b. Ubeyd b. Yahyâ Buhtürî, Dîvânu'l-Buhtürî, thk. Hasan Kamil es-Sayrafî (Kahire: Dâru'l-Maârif, 1963), 2/1230.

66 Buhtürî, Dîvânu'l-Buhtürî, 2/1230. 
için bir nevi 'mücevherle dolu olan bir ağızdan ancak mücevher dökülebilir' anlamına gelebilecek hoş ve kibar bir iltifatta bulunmuştur. ${ }^{67}$

Bazı edebî kaynaklarda yer alan ve kime nispet edildiği hususunda net bir açıklama bulunmayan aşağıdaki beyitlerde de değerli taşlar üzerinden güzel sözün önemi ve kıymeti vurgulanmak istenmiştir:

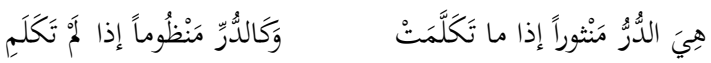

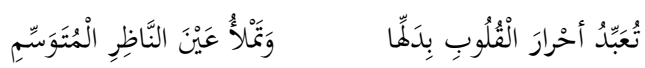

O, konuştuğunda etrafa saçılmış incidir;

Konuşmadığında anımsatıyor dizilmiş değerli taşları.

Köleleştiriyor nazıyla özgür gönülleri;

Ve dikkatlice bakan gözlere dolduruyor (yaşları). ${ }^{68}$

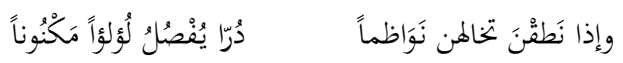

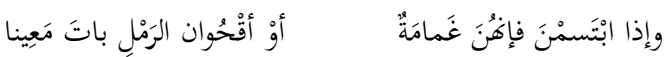

Konuştuklarında onları iyi korunan inci gerdanlı̆̆ının

Ayrılmış tanelerinin düzenleyicileri zannedersin.

Tebessüm ettiklerinde gerçekten de yağmur bulutu

Ya da bir pınara dönüşmüş kum papatyaları sanırsın. ${ }^{69}$

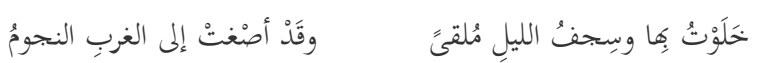

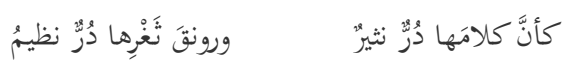

Örtüsü atılmışken gecenin ve yıldızlar

Batıya doğru dinlenmişken kaldım onunla baş başa;

Sözleri etrafa saçılmış inci misali,

67 İanlı şair Errecânî’ de Selçuklu veziri Nizamülmülk’ün (öl. 485/1092) onun gibi vezir olan bazı çocuklarını övdüğü 62 beyitlik kasidesini incilere ve değerli taşlara benzetmiştir. bk. Ebû Bekr Nâsihuddin Ahmed b. Muhammed el-Errecânî, Dîvânü'l-Errecânî, haz. Kadri Mayu (Beyrut: Dâru'lCîl, 1418/1998), 2/29-31.

68 Ebû Hilâl el-Askerî, Dîvânü'l-me ‘ânî, 1/482; Husrî, Zehrü'l-âdâb ve semerü'l-elbâb, 1/277; Ebü'lHasan Behâüddin Ali b. İsâ el-Erbilî, et-Težkiretü'l-fahriyye, thk. Hatim Salih ed-Dâmin (Dımaşk: Dâru'l-Beşâir, 1425/2004), 97.

69 Husrî, Husrî, Zehrü'l-âdâb ve semerü'l-elbâb, 1/40. 
Dişlerinin parlakliğ ise benziyordu dizilmiş elmasa. ${ }^{70}$

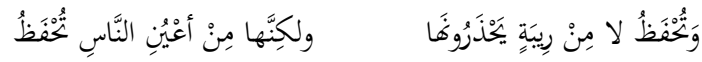

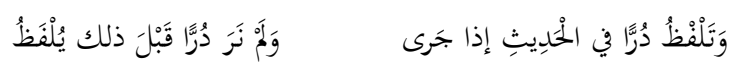

Korundu; fakat endişe duyulan bir töhmetten değil,

(Asıl korunması) bakan (o) gözlerden.

Incilerle telaffuz ediyor ki daha önce görmemiştik,

Konuşulduğunu inci misali sözlerden. ${ }^{71}$

Aktarılan beyitlerin tümünde güzel sözlerle birlikte inci ve elmaslara benzetilen dişlerden söz edildiği için burada hitap edilenlerin kadın olduğu anlaşılmaktadır. Elbette ki iltifat edilen kişinin cinsiyetine bakılmaz; ama amaç ruha dokunmaksa dillerden dökülen sevgi sözcükleri kadın veya erkeğe karşı farklılık arz edebilir. Binaenaleyh inci ve elmaslara benzetilen dişler üzerinden yapılan iltifatların kadınlara daha yakışık kalacağını söylemek yanlış olmayacaktır.

\subsection{Güvercin Gerdanlığına Benzetilmesi}

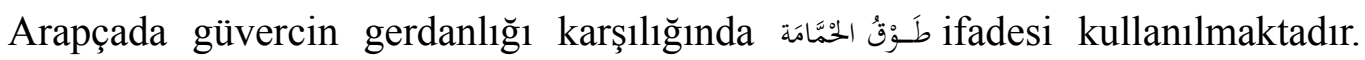

Edebiyatçılara göre bu ifadeden güvercinin boynunun etrafındaki yeşil, kırmızı ya da siyah tüyler kastedilir. ${ }^{72}$ Tufan felaketinden sonra Hz. Nuh (a.s.) tarafından su kaynağ1 bulmak üzere gönderilen güvercinin müjdeli bir haber getirmesi sonrasında Hz. Nuh'un ona dua ettiği ve bu yüzden bu denli güzel bir gerdanlıkla mükâfatlandırıldığı nakledilmiştir. ${ }^{73}$ Gerek güzelliği gerekse cazipliğinden olsa gerektir ki bazı âlimler

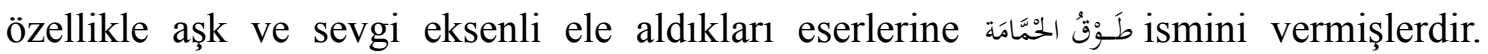

70 Ebü'l-Kāsım Alî b. el-Hüseyn b. Mûsâ b. Muhammed eş-Şerîf el-Murtazâ, Emâli'l-Murteżâ: Gurerü'l-fevâ'id ve dürerü'l-kalâ'id, thk. Muhammed Ebü'l-Fazl İbrâhim (Kahire: Dâru İhyâi'lKutubi'l-Arabiyye, 11373/1954), 1/521.

71 Şerîf el-Murtazâ, Emâli'l-Murteżâ: Gurerü'l-fevâ 'id ve dürerü'l-kalâ'id, 1/521.

72 Ebü'l-Bekā Kemâlüddîn Muhammed b. Mûsâ b. Îsâ Demîrî, Hayâtü'l-hayevân el-kübrâ, thk. İbrahim Salih (Dımaşk: Dâru'l-Beşâir, 1426/2005), 2/106; Ebü'l-Fazl Celâlüddîn Abdurrahmân b. Ebî Bekr b. Muhammed es-Süyûtî, Mecmû 'un min resâ'ili 's-Süyn̂ṭ̂: Tavkü 'l-hamâme, thk. Bedrettin Abdülilah elAmrânî, (Beyrut: Dâru'l-Kutubi'l-İlmiyye, 1424/2003), 66.

73 Ebü'l-Kāsım Ümeyye b. Ebi's-Salt Abdillâh b. Ebî Rebîa b. Avf es-Sekafî, Dîvânu Ümeyye b. Ebi'șSalt (Beyrut: el-Mektebetü'l-Ehliyye, 1896), 18; Ebû Osmân Amr b. Bahr b. Mahbûb el-Câhiz, Kitâbü'l-Hayevân, thk. Abdüsselam Muhammed Harun (Mısır: Mektebetü'l-Bâbi'l-Halebî, 1385/1965), 2/321; 3/199. 
Örneğin İbn Hazm el-Endelüsî (öl. 456/1064) aşkın mahiyeti, muhtelif safhaları, belirtileri, göz işaretleri ve mektuplaşma gibi sevgi ve sevgiliye dair yazdığı eserine bu ismi vermiştir. ${ }^{74}$

Arap toplumunda طَوْقُ الحمَّامَمة ifadesinin, var olan bir nitelik ve özelliğin ölünceye kadar devam etmesi başka bir ifadeyle her zaman sabit kalacağının vurgulanmasına yönelik bir darb-1 mesel olarak kullanıldığına bakılırsa ${ }^{75}$ buradan güvercin gerdanlığına benzetilen bir söz için hem gönül okşayıcı ve estetik hem de etkisinin ömür boyu kalıcı olduğu şeklinde bir çıkarım yapılabilir.

Birçok edebî kaynakta Emevîler döneminin meşhur şairlerinden Ferezdak'1n (öl. 114/732) kendi sözlerini/şiirlerini güvercin gerdanlığına benzettiği bilgisi yer almaktadır. Anlatıldığına göre Haramoğlu kabilesinden biri Ferezdak’a sövdüğü için kabilesi tarafından huzuruna getirildiğinde ünlü şair hiç beklenmeyen bir şekilde şu beyitleri söylemiştir:

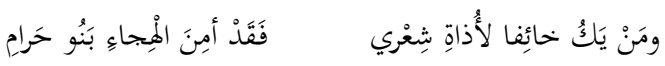

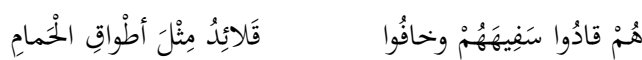

Şiirlerimin kendilerine eziyetinden korkanlar varsa,

Kesinlikle Haramoğulları hiciv(im)den emin olsunlar.

Kendilerinden olan çirkefi (bana) yönlendirdiler

Ve güvercin gerdanlığl misali kolyelerden korkuyorlar. ${ }^{76}$

Ferezdak, (öl. 114/732) kendisine hakaret eden kişiyi getiren kabile üyelerinin bu davranışını güzel addettiği için onlara asla sövmeyeceğini ikrar etmiştir. Bununla birlikte birini sövdüğü zaman ona yöneltilen eleştirilerin çıkarılması imkânsız olan bir

${ }_{74}$ Bkz. Ebû Muhammed Alî b. Ahmed b. Saîd b. Hazm el-Endelüsî el-Kurtubî, Tavku 'l-hamâme fi'lülfeti ve'l-üllâf, thk. Hasan Kamil es-Sayrafî (Kahire: y.y. 1369/1950). Celâlüddîn es-Süyûtî'nin de (öl. 911/1505) bu adla yazdığ bir risalesi bulunmaktadır.

75 Seâlibî, Simârü'l-kulûb fi'l-mużâf ve'l-mensûb, 378.

76 Câhiz, Kitâbü'l-Hayevân, 3/196; Ebû Alî el-Hasen b. Reşị̂ el-Ezdî el-Mesîlî el-Kayrevânî, el'Umde fì mehâsini'ş-şi'r ve âdâbih ve naḳdih, thk. Muhammed Muhyiddin Abdülhamîd (Beyrut: Dâru'l-Cîl, 1401/1981), 1/66; Seâlibî, Simârü'l-kulûb fi'l-mużâf ve'l-mensûb, 378, 379; İbn Hamdûn, et-Tezkiretü'l-Hamdûniyye, 5/403. 
gerdanlık gibi boynuna dolanacağını da açıkça belirterek şiirlerinin hem kalıcı etkisini hem de güzelliğini vurgulamaya çalışmıştır.

Rivayete göre Ebû Muhammed Yahyâ b. Eksem b. Muhammed’in (öl. 242/857) daha çok hicivleriyle tanınan şair Muhammed b. Hâzim b. Amr el-Bâhilî’ye inşâd ettiği kasidelerinin neden kısa olduğunu sorması ve yermesi üzerine kendisi şu şekilde cevap vermiştir:

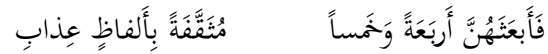

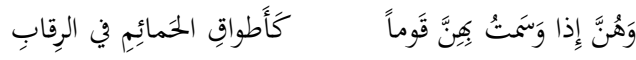

Onları (beyitleri) tatlı sözlerle bezeyerek,

Dörder-beşer (söyleyip) gönderiyorum.

Onlarla bir kavmi nitelediğimde

Güvercinlerin boyunlarındaki gerdanlık gibi görüyorum. ${ }^{77}$

Güvercin gerdanlığından söz eden diğer bir şair Şerîf er-Radî’dir (öl. 406/1015). Aslında şair doğrudan güzel sözü güvercin gerdanlığına benzetmemişse de aşağıda yer verilen beyitlerinden onun yumuşak ve karakteristik eylemleri sözlü iletişim gibi

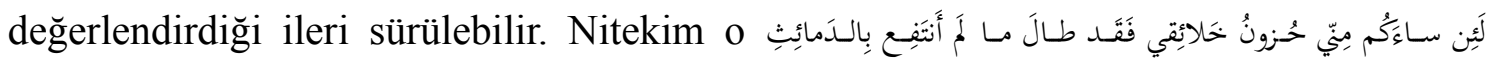
"Ĕ̆er mizacımın yumuşaklı̆̆ı sizi kırdıysa (bilin ki) uzun süren bu mülayim huyumdan bir yarar sağlamamışım." anlamına gelen beyti ile bir nevi hiç kimsenin kendisinden

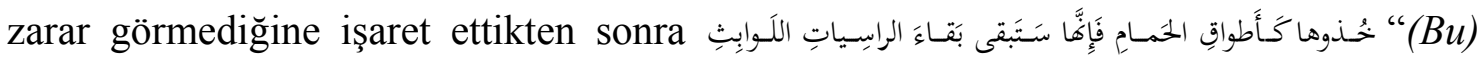
güvercin gerdanlı̆̆ına benzeyen yumuşak huylarımı benimseyin! Zira onlar yerinde sabit ve sarsılmaz yüksek dağlar gibi kalıcıdır." ${ }^{17}$ diyerek ahlaki güzelliğe benzetmeler eşliğinde bir değer yüklemiş ve onu iyilikle özdeşleştirmeye çalışmıştır. Yani ona göre ahlaki anlamda bir yumuşaklığın güzel neticeler verebilmesi için hem güvercin gerdanlığı gibi sabit hem de dağlar gibi sarsılmaz olmalıdır.

77 Muhammed b. Hâzim b. Amr el-Bâhilî, Dîvânu'l-Bâhilî Muhammed b. Hâzim haz. Muhammed Hayr el-Bukâ'î (Dımaşk: Dâru Kuteybe, 1402/1982), 24. Seâlibî, Simârü'l-kulûb fi'l-mużâf ve’l-mensûb, 379.

78 Ebü'l-Hasen Muhammed b. el-Hüseyn b. Mûsâ b. Muhammed eş-Şerîf er-Radî, Dîvânü'ş-Şerîf erRaḍ̂, thk. Mahmûd Mustafa Halâvî (Beyrut: Şerîketu Dâri'l-Erkam, 1419/1999), 1/298. 
Güzel sözle ilgili, birden fazla beyit tespit edilemediğinden dolayı alt başlıklar şeklinde ele alınmasına gerek duyulmayan şu benzetmeler de yapılagelmiştir:

Çiçek, ${ }^{79}$ su, ${ }^{80}$ suyolu, ${ }^{81}$ yağmur, ${ }^{82}$ yağmur damlasının verdiği tat, ${ }^{83}$ büyük kayalar, ${ }^{84}$ yıldızlar, ${ }^{85}$ misk, ${ }^{86}$ yumuşaklık, ${ }^{87}$ iffet, ${ }^{88}$ şeref ve yücelik, ${ }^{89}$ cömertlik vesilesi, ${ }^{90}$ itidallik, ${ }^{91}$ şifa kaynağı, ${ }^{92}$ hava, ${ }^{93}$ sağlık, ${ }^{94}$ şarap, ${ }^{95}$ sarhoşluk, ${ }^{96}$ serbest bırakılan esirler, ${ }^{97}$ rengârenk ve süslemeli kumaşlar, ${ }^{98}$ gri doğan kuşunun göğsü, ${ }^{99}$ tavus kuşunun kanatları, ${ }^{100}$ yeni doğum yapmış develerin sütü, ${ }^{101}$ taze hurma, ${ }^{102}$ gençlik günleri ${ }^{103}$ ve

79 Ebû Mansûr Abdülmelik b. Muhammed b. İsmâîl es-Seâlibî, el-Müntehal, haz. Ahmed Ebû Ali (İskenderiye: el-Matbaatü’t-Ticâriyye, 1319/1901), 9.

80 Seâlibî, el-Müntehal, 13.

81 Seâlibî, el-Müntehal, 24.

82 Ebû Zekeriyyâ Yahyâ b. Alî b. Muhammed el-Hatîb et-Tebrîzî, Şerḥu Dîvâni Ebî Temmâm, haz. Râcî el-Esmer (Beyrut: Dâru'l-Kitâbi'l-Arabî, 1414/1994), 1/101; İbn Kuteybe, 'Uyûnü'l-ahbâr, 4/82.

83 Câhiz el-Beyân ve't-tebyîn, $1 / 278$.

84 Hatîb et-Tebrîzî, Serhu Dîvâni Ebî Temmâm, 1/101.

85 Hatîb et-Tebrîzî, Serhu Dîvâni Ebî Temmâm, 1/101.

86 Seâlibî, el-Müntehal, 13, 16.

87 Ebû Abdillâh Kâ‘b b. Mâlik b. Ebî Kâ‘b Amr el-Ensârî, Dîvânu Ka'b b. Mâlik el-Enșârî, thk. Sâmî Mekkî el-Ânî (Bağdad: Mektebetü'l-Maârif, 1386/ 1966), 181; Behâüddin el-Erbilî, et-Tezkkiretü’lfahriyye, 55.

88 Kâ'b b. Mâlik el-Ensârî, Dîvânu Ka'b b. Mâlik el-Enșârî, 181.

89 Abdülkerîm en-Nehşelî, el-Mumti' $f \grave{i}$ șan 'ati'ş-şi $r$, thk. Muhammed Zağlul Selam (İskenderiye: Menşe'etü'l-Maârif, ts.), 124.

90 Hâtim Salih ed-Dâmin, Şi 'ru Bekir b. en-Nețtah (Bağdad: Matbaarü'l-Maârif, 1395/1975), 6.

91 Ebü'l-Hâris Zürrumme Gaylân b. Ukbe b. Ma‘dî b. Amr el-Kahtânî, Dîvânu Zirrumme, nşr. Ahmed Hasan Besec (Beyrut: Dâru'l-Kutubi'l-İlmiyye, 1415/1995), 104.

92 Sadrüddin Ali b. Ebi'l-Ferec b. el-Hasan el-Basrî, el-Hammâsetü'l-Bașriyye, thk. Adil Süleyman Cemal (Kahire: Mektebetü'l-Hânecî, 1420/1999), 3/1221.

93 Behâüddin el-Erbilî, et-Tezkiretü'l-fahriyye, 96.

94 Şerîf er-Radî, Dîvânü̈'ş-Şerîf er-Raḍ̂̀, $1 / 298$.

95 Beşşâr b. Bürd, Dîvânu Şi 'ri Beşşâr b. Bürd, 144; Câhiz, el-Beyân ve't-tebyîn, 1/277; İbn Kuteybe, 'Uyûnü'l-ahbâr, 4/83; Abdüsselâm Muhammed Hârûn, Mecmû 'atü'l-me 'ânî, 2/994.

96 İbn Kuteybe, 'Uyûnü'l-ahbâr, 4/82.

97 Seâlibî, el-Müntehal, 16.

98 Câhiz el-Beyân ve't-tebyîn, 1/278; Serî er-Reffâ, el-Muhib ve'l-mahbûb ve'l-meşmûm ve'l-meşrûb, $1 / 155,150$.

99 Ebû Mansûr Abdülmelik b. Muhammed b. İsmâîl es-Seâlibî, Men ġābe 'anhü'l-mutrib, thk. Muhammed b. Selim el-Lebâyîdî (Lübnan: el-Mektebetü'l-Osmâniyye, 1209), 6.

100 Seâlibî, Men gāâe 'anhü'l-mutrib, 6.

101 Câhiz el-Beyân ve't-tebyîn, $1 / 278$.

102 Şerîf el-Murtazâ, Emâli'l-Murtė̇â: Gurerü'l-fevâ'id ve dürerü'l-kalâ'id, 1/521; Serî er-Reffâ, elMuhib ve'l-maḥbûb ve'l-meşmûm ve'l-meşrûb, 1/155, 164.

103 Ebû İshâk İbrâhîm b. Muhammed b. Ahmed Ebî Avn el-Bağdâdî, Kitâbü 't-Teşbîhât, nşr. Muhammed Abdülmuîd Han (London: Matbaatu Câmiati Cambridge, 1950). 305; Abdüsselâm b. Muhammed b. Hârûn b. Abdirrâzık, Mecmû 'atü'l-me 'ânî (Beyrut: Dâru'l-Cîl, 1412/1992), 2/860. 
gençlerin karşılıklı gülüşmeleri. ${ }^{104}$ Bütün bu benzetmeler hicivlerle dolu klasik Arap edebiyatının sevgi ağırlıklı duygusal ve heyecan verici alanını gözler önüne serdiği gibi edip ve şairlerin kendilerine özgü üslûp ve teşbihlerle söylenmemişi söylemeye çalışarak ince ve anlamlı mesajlar vermeye çalıştıklarını da ortaya koymaktadır.

\section{Sonuç}

Konuşurken sarf edilen cümle ve ifadelerin birer kuru gürültüden ibaret olmadığı ancak akla ve gönle hitap eden güzel manalarından anlaşılmaktadır. Bu yüzden sözü sükûta tercih edenler, iletişimde kullanılan dilin anlamlı olduğu kadar doğrudan veya dolaylı bir şekilde gönüle dokunabilme kabiliyetine sahip olmasına dikkat çekmişlerdir.

Güzelliğin sübjektif nitelikleri olmakla birlikte algısal bir hazzı oluşturması bakımından bazı estetik ifadeler her zaman hoş karşılanmıştır ki bunlardan bir tanesi de güzel sözün benzetildiği unsurlardır. Klasik Arap edebiyatında başta sihir, rengârenk bahçeler, bal, değerli taşlar ve güvercin gerdanlığ olmak üzere daha birçok unsura benzetilen güzel söz kimi benzetme cümlelerinde müşebbeh bih özelinde ayırt edici bir detayı da içinde barındırmaktadır. Nitekim sihre benzetildiğinde özellikle bu sihrin helal olduğu belirtilmiş, bala benzetilmesinde ise bedenin manevi şifa kaynağı olduğuna işaret edilmiştir. Güzel söz zaman zaman muhteşem manzaralı bahçelere de benzetilmiş, böylece sevgi beslenen bireylerden işitilen ifadelerin huzur vesilesi olduğuna işaret edilmeye çalışılmıştır. Ayrıca değerli taşlara benzetilen güzel sözün inci misali dişlere sahip olan kişilerin ağzından döküldüğü söylenirken bu kişilerin kadın olduklarına zamirler üzerinden işaret edilmiştir. Güvercin gerdanlığına benzetilmesinde ise çeşitli renklere sahip bu gerdanlığın diğer gerdanlıklar gibi çıkarılabilir olmadığına binaen sözün güzelliği ve cazipliğinin sabitliği ve devamlılığı vurgulanmıştır.

Öte yandan edip ve şairler tarafından güzel söz ile benzetilen unsurlar arasındaki ortak vasıflara dikkat çekilmesi amacıyla genelde benzetme edatı kullanılmış, bazen de benzeyen ile benzetilenin tamamen aynı olduğu izleminin oluşabilmesi için bu tür edâtlara yer verilmemiştir. Başka bir ifadeyle güzel söz ve benzetilen unsurlar

104 Câhiz el-Beyân ve’t-tebyîn, 1/281, 283. 
etrafında teşbih çeşitlerinden en fazla teşbih-i mufassal ve teşbih-i beliğ sanatları göze çarpmaktadır. Kimi beyitlerde de muhatabın ilgisini daha kolay çekebilmek için sözün güzelliği oldukça ayrıntılı sıfat cümleleri aracılığıyla açıklanmaya çalışılmıştır. 


\section{Kaynakça}

Abdüsselâm Muhammed Hârûn. Mecmû'atü'l-me'ânî. 2 Cilt. Beyrut: Dâru'l-Cîl, $1412 / 1992$.

Abdülkerîm en-Nehşelî el-Kayrevânî. el-Mumti' fì șan 'ati'ş-şi'r. thk. Muhammed Zağlul Selam. İskenderiye: Menşe'etü'l-Maârif, ts.

A'lem eş-Şentemerî, Ebü'l-Haccâc Yûsuf b. Süleymân b. Îsâ. Dîvânü Tarafe b. el- 'Abd Şerḥu'l-A 'lem eş-Şentemerî. nşr. Dürriyye el-Hatîb - Lutfî es-Sakkal. Beyrut: elMüessesetü'l-Arabiyye li'd-Dirâsât ve'n-Neşr, ts.

Basrî, Ali b. Ebi'l-Ferec b. el-Hasan Sadrüddin. el-Hammâsetü'l-Bașriyye. thk. Adil Süleyman Cemal. 4 Cilt. Kahire: Mektebetü'l-Hânecî, 1420/1999.

Buhtürî, Ebû Ubâde el-Velîd b. Ubeyd b. Yahyâ et-Tâî. Dîvânu'l-Buhtürî. thk. Hasan Kamil es-Sayrafî. 5 Cilt. Kahire: Dâru'l-Maârif, 3. Basım, 1963.

Buhtürî, Ebû Ubâde el-Velîd b. Ubeyd b. Yahyâ et-Tâî. el-Hamâse. haz. Kamil Mustafa Kahire: el-Matbaatü'r-Rahmaniyye, 1929.

Buhârî, Ebû Abdillâh Muhammed b. İsmâîl b. İbrâhîm. el-Câmi 'u'ș-șahîhh. 10 Cilt. Lübnân: Dâru't-Te'sîl, 1433/2013.

Câhiz Ebû Osmân Amr b. Bahr b. Mahbûb. Kitâbü'l-Hayevân. thk. Abdüsselam Muhammed Harun. 8 Cilt. Misır: Mektebetü'l-Bâbi'l-Halebî, 2. Basım $1385 / 1965$.

Câhiz, Ebû Osmân Amr b. Bahr b. Mahbûb. el-Beyân ve't-tebyîn. thk. Abdüsselâm Muhammed Hârûn. 4 Cilt. Kahire: Mektebetü'l-Hânecî, 7. Basım, 1418/1998.

Ceylan, Adem - Y1lmaz, Hasan. “Arapçada Güzel Sözler Derlemesi Nesrü’l-Leâlî’nin Mensur Bir Tercümesi”. Celal Bayar Üniversitesi Sosyal Bilimler Dergisi, 17/3 2019. doi.org/10.18026/cbayarsos.514544

Cirân el-Avd, Âmir b. el-Hâris en-Nümeyrî. Dîvânu Cîrân el-'Avd en-Nümeyrî. haz. Ahmed Nesim. Kahire: Matbaatu Dâri'l-Kutubi'l-Mısriyye, 3. Basım, 2000.

Cürcânî, Ebû Bekr Abdülkāhir b. Abdirrahmân b. Muhammed. Delâ'ilü'l-i cấz. nşr. Mahmûd Muhammed Şâkir. (Kahire: Mektebetü'l-Hânecî, 1404/1984.

Demîrî, Ebü'l-Bekā Kemâlüddîn Muhammed b. Mûsâ b. Îsâ. Hayâtü'l-hayevân elkübrâ. thk. İbrahim Salih. 4 Cilt. Dımaşk: Dâru'l-Beşâir, 1426/2005.

Ebû Hayyân et-Tevhîdî, Alî b. Muhammed b. Abbas. el-Beșâ'ir ve'ż-žehâ'ir. thk. Vedat el-Kâdî. 10 Cilt. Beyrut: Dâru Sâdır, 1408/1988.

Ebû Muâz Beşşâr b. Bürd el-Ukaylî. Dîvânu Şi 'ri Beşşâr b. Bürd. thk. Bedreddin elAlevî. Beyrut: Dâru's-Sekâfe, 1981.

Ebû Zeyd el-Kureşî. Cemheretü eş 'âri'l- 'Arab. thk. Ali Muhammed el-Bicâvî. Misır: Dâru Nahdeti Misır, 1981. 
Errecânî, Ebû Bekr Nâsihuddin Ahmed b. Muhammed. Dîvânü'l-Errecânî. haz. Kadri Mayu. 2 Cilt. Beyrut: Dâru'l-Cîl, 1418/1998.

Erbilî, Ebü'l-Hasan Behâüddin Ali b. İsâ. et-Tezkiretü'l-fahriyye. thk. Hatim Salih edDâmin. Dımaşk: Dâru'l-Beşâir, 1425/2004.

Ebü'l-Bekā el-Ukberî, Muhibbüddîn Abdullāh b. el-Hüseyn b. Abdillâh. et-Tibyân fî şerhi'd-Dîvân Şerḥu Dîvâni'l-Mütenebbî. nşr. Mustafa es-Sekkā vd. 4 Cilt. Beyrut: Dâru'l-Marife, ts.

Ebû Hilâl el-Askerî, el-Hasen b. Abdillâh b. Sehl. Cemheretü'l-emsâal. thk. Muhammed Ebü'l-Fazl İbrâhim - Abdülmecid Katâmiş. 2 Cilt. Beyrut: Dâru'l-Cîl, 2. Basım, $1408 / 1988$.

Ebû Hilâl el-Askerî, el-Hasen b. Abdillâh b. Sehl. Dîvânü'l-me 'ânî. thk. Ahmed Selim Gânim. 2 Cilt. b.y: Dâru'l-Garbi'l-İslâmî, 1424/2003.

Ebû Sa'd Süveyd b. Kâhil el-Yeşkûrî. Dîvânu Süveyd b. Ebî Kâhil el-Yeşkûrî. thk. Şakir el-Âşûr. Dımaşk: 3. Basım, 2012.

Ebû Ubeyd el-Bekrî, Abdullah b. Abdilazîz b. Muhammed b. Eyyûb b. Amr. Faṣlü'lmaḳāl fí şerḥi Kitâbi'l-Emsâal. thk. İhsan Abbas - Abdülmecid Âbidîn. Beyrut: Müessesetü'r-Risâle,1391/ 1971.

Ebû Züeyb el-Hüzelî, Huveylid b. Hâlid b. Muharris. Dîvâanu Ebî Zü'eyb el-Hüzelî. thk. Ahmed Halîl eş-Şâl. Port Said: Merkezü'd-Dirâsât ve'l-Buhûsi'l-İslâmiyye, $1435 / 2014$.

Fidâ Muhammed Ganim. "eț-Ṭabî‘atü'l-mâiye fî şi'ri'ș- Șanevberî”. Mecelletü'l-Belkâ' li'l-Buhûs ve'd-Dirâsât. 17/1 (2014), 81-105.

Hâtim Salih ed-Dâmin. Şi ‘ru Bekir b. en-Nețtah. Bağdad: Matbaarü'l-Maârif. 1395/1975.

Hassân b. Sâbit b. el-Münzir el-Ensârî. Dîvânu Hassân b. Sấbit. thk. Abede Mühennâ. Beyrut: Dâru'l-Kutubi'l-İlmiyye, 2. Basım, 1414/1994.

Hatîb et-Tebrîzî, Ebû Zekeriyyâ Yahyâ b. Alî b. Muhammed. Şerḥu Dîvâni 'Antere. nşr. Mecîd Tarrâd. Beyrut: Dâru'l-Kitâbi'l-Arabî, 1412/1992.

Hatîb et-Tebrîzî, Ebû Zekeriyyâ Yahyâ b. Alî b. Muhammed. Şerḥu Dîvâni Ebî Temmâm. haz. Râcî el-Esmer. 2 Cilt. Beyrut: Dâru'l-Kitâbi'l-Arabî, 1414/1994.

Hatîb et-Tebrîzî, Ebû Zekeriyyâ Yahyâ b. Alî b. Muhammed. Şerḥu Dîvâni Zirrumme. Beyrut: Dâru'l-Kitâbi'l-Arabî, 2. Basım, 1416/1996.

Husrî, Ebû İshâk İbrâhîm b. Alî b. Temîm el-Ensârî. Zehrü'l-âdâb ve semerü'l-elbâb. haz. Selahüddin el-Hevârî. 4 Cilt. Beyrut: el-Mektebetü'l-Asriyye Seydâ, $1421 / 2001$.

İbn Abdirabbih, Ebû Ömer Şihâbüddîn Ahmed b. Muhammed. el- İ́kdü'l-ferîd. thk. Müfid Muhammed Kumayha. 9 Cilt. Beyrut: Dâru'l-Kutubi'l-İlmiyye, 1404/1983. 
İbn Abdilberr en-Nemerî, Ebû Ömer Cemâlüddîn Yûsuf b. Abdillâh b. Muhammed. Behcetü'l-mecâlis ve ünsü'l-mücâlis ve şaḥzüzz-zâhini ve'l-hâcis. thk. Muhammed Mürsî el-Hûlî. 2 Cilt. Beyrut: Dâru'l-Kutubi'l-İlmiyye, 2. Basım, $1402 / 1982$.

İbn Ebü'd-Dünyâ, Ebû Bekr Abdullah b. Muhammed. Kitâbu'ṣ-Sumt ve âdâbü'l-lisân. thk. Necm Abdurrahman Halef. Beyrut: Dâru'l-Garbi'l-İslâmî, 1406/1986.

İbnü'l-Enbârî, Ebü'l-Berekât Kemâlüddîn Abdurrahmân b. Muhammed. Nüzhetü'lelibbâ' fì tabakâti'l-üdebâ'. thk. İbrahim es-Sâmirâî. Ürdün: Mektebetü'lMennâr, 1405/1985.

İbn Ebû Avn, Ebû İshâk İbrâhîm b. Muhammed b. Ahmed b. Ebî Avn. Kitâbü't-Teşbîhât. nşr. Muhammed Abdülmuîd Han. London: Matbaatu Câmiati Cambridge, 1950.

İbn Hazm, Ebû Muhammed Alî b. Ahmed b. Saîd. Tavku'l-hamâme fi'l-ülfeti ve'l-üllâf. thk. Hasan Kamil es-Sayrafî. Kahire: y.y. 1369/1950.

İbn Hamdûn, Ebü'l-Meâlî Bahâüddîn Muhammed b. el-Hasen. et-Teżkiretü'lHamdûniyye. thk. İhsan Abbas - Bekir Abbas. 10 Cilt. Beyrut: Dâru Sâdır, 1996.

İbn Kuteybe ed-Dîneverî, Ebû Muhammed Abdullāh b. Müslim. 'Uyûnü'l-ahbârr. 4 Cilt. Beyrut: Dâru'l-Kitâbi'l-Arabî, 1343/1925.

İbn Kuteybe ed-Dîneverî, Ebû Muhammed Abdullāh b. Müslim. eş-Şi 'r ve'ş-şu 'arâ'. thk. Ahmed Muhammed Şakir. 2 Cilt. Kahire: Dâru'l-Maârif, 1377/1957.

İbn Receb, Ebü'l-Ferec Zeynüddîn Abdurrahmân b. Ahmed b. Abdirrahmân. Lețâ 'ifü'lma 'ârif fìmâ li-mevâsimi'l- 'âm mine'l-vezấ if. thk. Yasin Muhammed es-Sevvâs. Beyrut: Dâru İbn Kesîr, 5. Basım, 1420/1999.

İbn Reşîk el-Kayrevânî, Ebû Alî el-Hasen b. Reşîk el-Ezdî el-Mesîlî. el-'Umde fî mehâsini'ş-şi 'r ve âdâbih ve nakdih. thk. Muhammed Muhyiddin Abdülhamîd. 2 Cilt. Beyrut: Dâru'l-Cîl, 5. Basım, 1401/1981.

İbnü'ş-Şecerî, Ebü's-Saâdât Ziyâüddîn Hibetullah b. Alî b. Muhammed. Muhtârâtü şu 'arâ'i'l- 'Arab. thk. Ali Muhammed el-Bicâvî. Beyrut: Dâru'l-Cîl, 1412/1992.

İbn Teymiyye, Ebü'l-Abbâs Takıyyüddîn Ahmed b. Abdilhalîm b. Mecdiddîn. Mecmû ‘u fetâvâ. nşr. Abdurrahman b. Muhammed b. Kasım. 37 Cilt. Medine: Mücemmeü'l-Melik Fehd li't-Tabbâati'l-Mushafi'ş-Şerîf, 1425/2004.

Kâ‘b b. Mâlik el-Ensârî, Ebû Abdillâh. Dîvânu Ka'b b. Mâlik el-Enșârî. thk. Sâmî Mekkî el-Ânî. Bağdad: Mektebetü'l-Maârif, 1386/ 1966.

Karaarslan, Nasuhi Ünal. "Sanevberî”. Türkiye Diyanet Vakfi İslâm Ansiklopedisi. Erişim 6 Ekim 2021. https://islamansiklopedisi.org.tr/sanevberi

Karaman, Gülay. Klasik Türk Edebiyatında Sihir. Kocaeli: Kocaeli Üniversitesi, Sosyal Bilimler Enstitüsü, Doktora Tezi, 2015. 
Kazan, Ahmet. Gazzali'nin İhyau Ulumi'd-din Adlı Eserinin 3-4. Ciltlerindeki Güzel Sözler ve Kaynaklart. İstanbul: Marmara Üniversitesi, Sosyal Bilimler Enstitüsü, Yüksek Lisans Tezi, 2009.

Küşâcim, Ebü'l-Feth Mahmûd b. el-Hüseyn b. es-Sindî b. Şâhek. Dîvânu Küşâcim. thk. Nebevî Abdülvâhid Şa'lân. Kahire: Mektebetü’l-Hânecî, 1417/1997.

Mâverdî, Ebü'l-Hasen Alî b. Muhammed b. Habîb el-Basrî. Edebü'd-dünyâ ve'd-dîn. haz. Komisyon. Beyrut: Dâru'l-Minhâc, 1434/2013.

Müberred, Ebü'l-Abbâs Muhammed b. Yezîd b. Abdilekber. el-Kâmil fi'l-edeb. thk. Muhammed Ahmed ed-Dâlî. 3 Cilt. Beyrut: Müessesetü'r-Risâle, 3. Basım, 1412/1992.

Mütenebbî, Ebü't-Tayyib Ahmed b. el-Hüseyn b. el-Hasen. Dîvânü'l-Mütenebbî. Beyrut: Dâru Beyrut, 1403/1983.

Râgıb el-İsfahânî, Ebü'l-Kāsım Hüseyn b. Muhammed b. el-Mufaddal. Muhâdarâtü'lüdebâ' ve muhâverâtü'ş-şu 'arâ' ve'l-büleg $\bar{a}^{\prime}$. haz. İbrahim Zeydân. Misır: Mektebetü'l-Hilâl, 1902.

Sâbit b. Ebû Sâbit. Saîd el-Kûfî el-Lugavî. Halku'l-insân. thk. Abdüssettâr Ahmed Ferrâc. Kuveyt: Matbaatu Hukûmeti Kuveyt, 1985.

Serî er-Reffâ', Ebü'l-Hasen es-Serî b. Ahmed. el-Muhib ve'l-mahbû́b ve'l-meşmûm ve'l-meşrûb. thk. Teiletion von Misbâh Galâvuncî. 4 Cilt. Dımaşk: Matbûâtu Macmai'l-Lügati'l-Arabiyye, 1407/1986.

Seâlibî, Ebû Mansûr Abdülmelik b. Muhammed b. İsmâîl. el-Müntehal. haz. Ahmed Ebû Ali. İskenderiye: el-Matbaatü't-Ticâriyye, 1319/1901.

Seâlibî, Ebû Mansûr Abdülmelik b. Muhammed b. İsmâîl. Men gāābe 'anhü'l-mutrib. thk. Muhammed b. Selim el-Lebâyîdî. Lübnan: el-Mektebetü'l-Osmâniyye, 1209.

Seâlibî, Ebû Mansûr Abdülmelik b. Muhammed b. İsmâîl. Yetîmetü'd-dehr fî mehâsini ehli'l- 'aṣr. thk. Müfîd Muhammed Kumeyha. 5 Cilt. Beyrut: Dâru'l-Kutubi'lİlmiyye, 1403/1983.

Seâlibî, Ebû Mansûr Abdülmelik b. Muhammed b. İsmâîl. Simârü'l-kulûb fi'l-mużâf ve'l-mensûb. thk. Muhammed Ebü'l-Fazl İbrâhim. Beyrut: el-Mektebetü'lAsriyye Seydâ, 1424/2003.

Siracüddin Muhammed. Mevsû'atu revâi 'i'ş-şi 'ri'l-'Arabî. 10 Cilt. Beyrut: Dâru'rRâtibi'l-Câmiiyye, ts.

Sükkerî, Ebû Saîd el-Hasen b. el-Hüseyn b. Ubeydillâh el-Atekî. Dîvânü Ebi'l-Esved ed-Dü'elî. thk. Muhammed Hasan Âl Yasin. Beyrut: Dâru Mektebeti'l-Hilâl, 1418/1998.

Sükkerî, Ebû Saîd el-Hasen b. el-Hüseyn b. Ubeydillâh el-Atekî. Şi 'ru'l-Ahțal. thk. Fahrettin Kabave. Dımaşk: Dâru'l-Fikr, 4. Basım, 1416/1996. 
Süyûtî, Ebü'l-Fazl Celâlüddîn Abdurrahmân b. Ebî Bekr b. Muhammed. Mecmû 'un min resâ'ili 's-Süyuttî: Tavkü'l-hamâme. thk. Bedrettin Abdülilah el-Amrânî. Beyrut: Dâru'l-Kutubi'l-İlmiyye, 1424/2003.

Şâfiî, Ebû Abdillâh Muhammed b. İdrîs b. Abbâs. Dîvânu'l-Imâmi'ş-Şâfi 'î. haz. Ömer et-Tebbâ'. Beyrut: Dâru'l-Erkam bin Ebi'l-Erkam, 1416/1995.

Şerîf er-Radî, Ebü'l-Hasen Muhammed b. el-Hüseyn b. Mûsâ b. Muhammed. Dîvânü'şŞerîf er-Raḍ̂. thk. Mahmûd Mustafa Halâvî. 2 Cilt. Beyrut: Şerîketu Dâri'lErkam, 1419/1999.

Şerîf el-Murtazâ, Ebü'l-Kāsım Alî b. el-Hüseyn b. Mûsâ b. Muhammed. Emâli'lMurteżâ: Gurerü'l-fevâ'id ve dürerü'l-kalâ'id. thk. Muhammed Ebü'l-Fazl İbrâhim. 2 Cilt. Kahire: Dâru İhyâi'l-Kutubi'l-Arabiyye, 11373/1954.

Tarafe b. el-Abd, Dîvânu Tarafe b. el-'Abd. haz. Mehdi Muhammed Nâsirüddîn. Beyrut: Dâru'l-Kutubi'l-İlmiyye, 1423/2002.

Ümeyye b. Ebi's-Salt, Abdillâh b. Ebî Rebîa b. Avf es-Sekafî. Dîvânu Ümeyye b. Ebi'ṣSalt. Beyrut: el-Mektebetü'l-Ehliyye, 1896.

Veşşâ', Ebü’t-Tayyib Muhammed b. Ahmed b. İshâk b. Yahyâ. Kitâbü'l-Müveşşâ: ezZarf ve'z-zurefầ'. thk. Kemal Mustafa. Misır: Mektebetü'l-Hânecî, 1372/1953.

Yemân b. Ebi'l-Yemân el-Bendenîcî. et-Takfiyye fi'l-luġa. thk. Halil İbrahim el-Atiyye. Bağdad: Matbaatu'l-Ânî, 1976.

Zürrumme, Ebü'l-Hâris Gaylân b. Ukbe el-Kahtânî. Dîvânu Zürrumme. haz. Ahmed Hasan Besec. Beyrut: Dâru'l-Kutubi'l-İlmiyye, 1415/1995.

Züheyr b. Ebî Sülmâ el-Müzenî, Dîvânu Züheyr b. Ebû Sülmâ. haz. Ali Hasan Fâur. Beyrut: Dâru'l-Kutubi'l-İlmiyye, 1408/1988. 